Article

\title{
Comparison of Effects of Sodium Bicarbonate and Sodium Carbonate on the Hydration and Properties of Portland Cement Paste
}

\author{
Yuli Wang ${ }^{1}$, Fengxia He ${ }^{1}$, Junjie Wang ${ }^{2, *}$ and Qianku $\mathrm{Hu}^{1}$ \\ 1 School of Materials Science and Engineering, Henan Polytechnic University, Jiaozuo 454003, China; \\ wangyuli@hpu.edu.cn (Y.W.); hefengxia321@163.com (F.H.); hqk@hpu.edu.cn (Q.H.) \\ 2 Division of Engineering, New York University Abu Dhabi, Abu Dhabi P.O. Box 129188, UAE \\ * Correspondence: jw4777@nyu.edu
}

Received: 3 March 2019; Accepted: 21 March 2019; Published: 28 March 2019

\begin{abstract}
Carbonates and bicarbonates are two groups of accelerators which can be used in sprayed concrete. In this study, the effects of the two accelerators sodium carbonate $\left(\mathrm{Na}_{2} \mathrm{CO}_{3}\right)$ and sodium bicarbonate $\left(\mathrm{NaHCO}_{3}\right)(0 \%, 1 \%, 2 \%, 3 \%$, and $4 \%$ by weight of ordinary Portland cement $\mathrm{OPC})$ on the properties of OPC paste were compared. The results show that both of them could accelerate the initial and final setting time of OPC paste, but the effect of the two accelerators on the compressive strength were different. After 1 day, sodium bicarbonate at $3 \%$ had the highest strength while sodium carbonate at $1 \%$ had the highest strength. After 7 days, both of the two accelerators at $1 \%$ had the highest compressive strength. After 28 days, the compressive strength decreased with the increase of the two. The improved strength at 1 and 7 days was caused by the accelerated formation of ettringite and the formation of $\mathrm{CaCO}_{3}$ through the reactions between the two with portlandite. The decrease of strength was caused by the $\mathrm{Na}^{+}$could reduce the adhesion between C-S-H gel by replacing the $\mathrm{Ca}^{2+}$. $\mathrm{NaHCO}_{3}$ was found be a better accelerator than $\mathrm{Na}_{2} \mathrm{CO}_{3}$.
\end{abstract}

Keywords: $\mathrm{NaHCO}_{3} ; \mathrm{Na}_{2} \mathrm{CO}_{3}$; portland cement; compressive strength; setting time

\section{Introduction}

Rapid hardening ability and high early strength are essential properties for shotcrete or sprayed concrete. Different accelerators were usually used in order to meet these requirements [1-9]. The mostly used accelerators including alkali carbonates, alkali hydroxide, alkali silicate, and alkali aluminate. For example, the sodium silicate was found to be able to modify the ITZ between the cement paste and aggregates and decrease the porosity of mortar [10]. Sodium aluminate and potassium aluminate can accelerate the formation of ettringite in the cement paste, and thus cause a rapid hardening effect [11]. Sodium aluminate was reported to be able to modify the pore structure of cement paste at an early age, improve the resistance to chloride ingress, and increase early-age compressive strength [12]. Carbonates [7,13-17] and bicarbonates with alkali were also among the most-used accelerators, such as $\mathrm{Na}_{2} \mathrm{CO}_{3}$ and $\mathrm{NaHCO}_{3}$ [18-22]. Mathur and Sharma [23] reported that the $\mathrm{NaHCO}_{3}$ can improve the strength and porosity of cement paste. Chandrawat and Yadav [24] found that the $\mathrm{Na}_{2} \mathrm{CO}_{3}$ could enhance the compressive strength and durability of cement paste. The work of Kunther et al. [25] showed that the bicarbonate ions could reduce the expansion of mortar and improve the sulfate resistance of mortar when subjected to sulfate attack. Yang et al. [26] reported that the addition of $\mathrm{NaHCO}_{3}$ and calcium lignosulphonate together could accelerate the formation of ettringite in the fly ash cement paste by changing the liquid-phase composition and the status of ettringite crystallization. Jang et al. [20] showed that the addition of $1 \%$ and $2 \% \mathrm{NaHCO}_{3}$ could accelerate the hydration of 
cement paste and improve both flexural and compressive strength of the mortar specimen, but the addition of above $5 \% \mathrm{NaHCO}_{3}$ caused the adverse effect on the strength development because of the formation of strong alkali $\mathrm{NaOH}$ in the specimen. Reddy et al. [27], however, reported that the both of $\mathrm{Na}_{2} \mathrm{CO}_{3}$ and $\mathrm{NaHCO}_{3}$ could decrease the compressive and tensile strength of concrete regardless of the content added or test age, and they also reported a significant reduction of strength after 28 days. However, Reddy and Krishna [28] reported that either $\mathrm{Na}_{2} \mathrm{CO}_{3}$ or $\mathrm{NaHCO}_{3}$ could increase the early age strength at 3 and 7 days but decrease significantly the strength after 28 days, besides, they reported that $\mathrm{Na}_{2} \mathrm{CO}_{3}$ accelerated the setting time whereas the $\mathrm{NaHCO}_{3}$ retarded the setting time. In addition, the structure and shape of the interface transition zone between the slurry and the aggregate in the cement composite material is a complicated problem. It has been well accepted that $[29,30]$ the cement-based interface transition zone of the coarse aggregate is the weakest unit in the concrete, and the fly ash as mineral additive has a positive impact on the performance improvement of the interface transition zone.

It can be seen that there exist conflicted findings on the influence of $\mathrm{Na}_{2} \mathrm{CO}_{3}$ and $\mathrm{NaHCO}_{3}$ on the setting time and physical properties of cementitious materials. It is necessary to carry out a comprehensive study on the effects of the two accelerators on the properties of cement paste and make a comparison between the two. In order to investigate and compare the effects of the two accelerators on the properties of OPC paste, the same amount of $\mathrm{Na}_{2} \mathrm{CO}_{3}$ and $\mathrm{NaHCO}_{3}$ with $0 \%, 1 \%, 2 \%, 3 \%$, and $4 \%$ weight of OPC were added into different mixes and the setting time and compressive strength at ages of 1,7 , and 28 days were studied, besides, the related hydration mechanism and hydration products were investigated through hydration heat, Thermogravimetry-Differential Thermal Analysis (TG-DTA), X-ray Diffraction (XRD), and Scanning Electron Microscopy (SEM) tests.

\section{Materials and Methods}

\subsection{Materials}

P.O. 42.5 ordinary Portland cement (OPC) in accordance with a Chinese standard GB175-2007 [31] was used. The physical properties and chemical composition of OPC are shown Tables 1 and 2. The mineral composition of OPC is shown in Table 3. The $\mathrm{NaHCO}_{3}$ and $\mathrm{Na}_{2} \mathrm{CO}_{3}$ used were in powder form and the purity was $>99.5 \%$ and $>99.8 \%$, respectively. A superplasticizer used was polycarboxylate. The mixing water was deionized water.

Table 1. Physical properties of ordinary Portland cement (OPC).

\begin{tabular}{cccccccc}
\hline \multirow{2}{*}{ Fineness/\% } & \multirow{2}{*}{ Stability } & \multicolumn{2}{c}{ Setting Time/min } & \multicolumn{2}{c}{ Flexural Strength/MPa } & \multicolumn{2}{c}{ Compressive Strength/MPa } \\
\cline { 3 - 8 } & & Initial & Final & 3 days & 28 days & 3 days & 28 days \\
\hline \multirow{2}{*}{1.5} & Qualified & 181 & 378 & 5.1 & 9.3 & 25.3 & 51.6 \\
\hline
\end{tabular}

Table 2. Chemical composition of OPC $/ \%$.

\begin{tabular}{cccccccc}
\hline $\mathrm{SiO}_{2}$ & $\mathrm{CaO}$ & $\mathrm{Al}_{2} \mathrm{O}_{3}$ & $\mathrm{Fe}_{2} \mathrm{O}_{3}$ & $\mathrm{MgO}$ & $\mathrm{Na}_{2} \mathrm{O}$ & $\mathrm{K}_{\mathbf{2}} \mathrm{O}$ & $\mathrm{LOI}$ \\
\hline 22.96 & 63.87 & 5.73 & 3.31 & 2.64 & 0.32 & 0.23 & 0.18 \\
\hline
\end{tabular}

Table 3. Mineral composition of OPC/\%.

\begin{tabular}{cccc}
\hline $\mathrm{C}_{3} \mathrm{~S}$ & $\mathrm{C}_{2} \mathrm{~S}$ & $\mathrm{C}_{3} \mathrm{~A}$ & $\mathrm{C}_{4} \mathrm{AF}$ \\
\hline 54.5 & 19.23 & 8.36 & 10.14 \\
\hline
\end{tabular}

\subsection{Methods}

The mix design is shown in Table 4. Water-cement ratio (w/c) was kept same as 0.35. The superplasticizer was kept same as $0.5 \%$ by weight of OPC. OPC was firstly mixed with $\mathrm{NaHCO}_{3}$ 
or $\mathrm{Na}_{2} \mathrm{CO}_{3}$ in dry state. The water and superplasticizer were then added and mixing speed was at $60 \mathrm{rpm}$ for $2 \mathrm{~min}$ followed by $120 \mathrm{rpm}$ for another $2 \mathrm{~min}$. The weight of $\mathrm{NaHCO}_{3}$ and $\mathrm{Na}_{2} \mathrm{CO}_{3}$ were added as $1 \%, 2 \%, 3 \%$, and $4 \%$ by weight of cement in different mixes. Specimens were cured under $\mathrm{s}$ standard curing condition $\left(20^{\circ} \mathrm{C}, 97 \%\right.$ R.H.).

Table 4. Mix design.

\begin{tabular}{cccccc}
\hline Mix ID & OPC/\% & Superplasticizer/\% & $\mathrm{NaHCO}_{3} / \%$ & $\mathrm{Na}_{2} \mathrm{CO}_{3} / \%$ & W/C \\
\hline 1 & & 0 & 0 & \\
2 & & 1 & - & \\
3 & & 2 & - & \\
4 & & 3 & - & \\
5 & \multirow{2}{*}{00} & & - & - & 0.35 \\
6 & & & - & 1 & \\
7 & & - & 2 & \\
8 & & - & 4 & \\
9 & & & 4 & \\
\hline
\end{tabular}

The setting time of cement paste were tested according to a Chinese standard JC477-2005 [32]. A multichannel microcalorimeter was used for hydration heat test and it lasted for $24 \mathrm{~h}$. Cubic samples with a dimension of $40 \mathrm{~mm} \times 40 \mathrm{~mm} \times 40 \mathrm{~mm}$ were used for compressive strength test. Compressive strength, TG-DTA, and SEM tests were conducted at ages of 1, 7, and 28 days. Powder samples were collected and the hydration was terminated by immersing into absolute ethyl alcohol for $24 \mathrm{~h}$. The powder samples were then dried at $40^{\circ} \mathrm{C}$ in a vacuum oven for $4 \mathrm{~h}$. The samples were furtherly grounded by a pestle and mortar to pass a sieve with an aperture of $75 \mu \mathrm{m}$. The final powder samples were used for TG-DTA and XRD tests. The TG-DTA tests were conducted in a $\mathrm{N}_{2}$ environment with a simultaneous thermal analyzer system (HENVEN, Beijing, China) and the temperature was increased from $20^{\circ} \mathrm{C}$ to $800{ }^{\circ} \mathrm{C}$ at a rate of $10^{\circ} \mathrm{C} / \mathrm{min}$. Each time, one gram of the powder sample was used for XRD test. The XRD tests were conducted using a Rigaku SmartLab X-ray diffractometer (Rigaku, Tokyo, Japan) under a voltage of $40 \mathrm{kV}$ and a current of $150 \mathrm{~mA}$. The scanning rate was $10^{\circ} / \mathrm{min}$ from $5^{\circ}$ to $70^{\circ}$. A MERLIN Compactfield Emission Scanning Electron Microscope (ZEISS, Jena, Germany) was used for SEM observations. The selected samples for SEM observations were at a size of around $5 \mathrm{~mm}$ in length and width with a fresh broken surface after the compression tests at ages of 1, 7, and 28 days. The samples were gold coated under vacuum condition before observation. The detailed procedures of hydration heat, compressive strength, TG-DTA, XRD, and SEM can also be found in our previous paper [33].

\section{Results}

\subsection{Influence of $\mathrm{NaHCO}_{3} / \mathrm{Na}_{2} \mathrm{CO}_{3}$ on the Setting Time of OPC Paste}

The influence of $0 \%, 1 \%, 2 \%, 3 \%$, and $4 \%$ of $\mathrm{NaHCO}_{3} / \mathrm{Na}_{2} \mathrm{CO}_{3}$ on the initial and final setting time of OPC paste is shown in Figure 1. The results show that both of the initial and final setting time of the OPC paste decreased with the increase of $\mathrm{NaHCO}_{3}$ or $\mathrm{Na}_{2} \mathrm{CO}_{3}$ content. The initial setting time of OPC paste with $1 \%, 2 \%, 3 \%$, and $4 \% \mathrm{NaHCO}_{3}$ decreased by $86.76 \%, 94.12 \%, 96.69 \%$, and $97.43 \%$ respectively compared to that of pure OPC paste. The final setting time of OPC paste with $1 \%, 2 \%, 3 \%$, and $4 \% \mathrm{NaHCO}_{3}$ decreased by $43.51 \%, 68.70 \%, 85.50 \%$, and $86.01 \%$ respectively compared to that of pure OPC paste. It can be seen that the addition of $1-2 \% \mathrm{NaHCO}_{3}$ significantly deceased the initial and final setting time of OPC paste. Further increase of $\mathrm{NaHCO}_{3}$ beyond $1 \%$ up to $4 \%$ showed little influence on the initial setting time, and further increase of $\mathrm{NaHCO}_{3}$ beyond $2 \%$ up to $4 \%$ showed little influence on the final setting time.

The initial setting time of OPC paste with $1 \%, 2 \%, 3 \%$, and $4 \% \mathrm{Na}_{2} \mathrm{CO}_{3}$ decreased by $90.44 \%$, $90.80 \%, 91.18 \%$, and $91.91 \%$ respectively compared to that of pure OPC paste. The final setting time 
of OPC paste with $1 \%, 2 \%, 3 \%$, and $4 \% \mathrm{Na}_{2} \mathrm{CO}_{3}$ decreased by $39.95 \%, 53.69 \%, 54.96 \%$, and $64.38 \%$ respectively compared to that of pure OPC paste. It can be seen that the influence of $\mathrm{Na}_{2} \mathrm{CO}_{3}$ on the initial setting time was more significant than the final setting time. The $\mathrm{Na}_{2} \mathrm{CO}_{3}$ showed similar effect as $\mathrm{NaHCO}_{3}$ on the initial setting time but its influence on the final setting time was less than the $\mathrm{NaHCO}_{3}$. The related mechanisms will be discussed later.

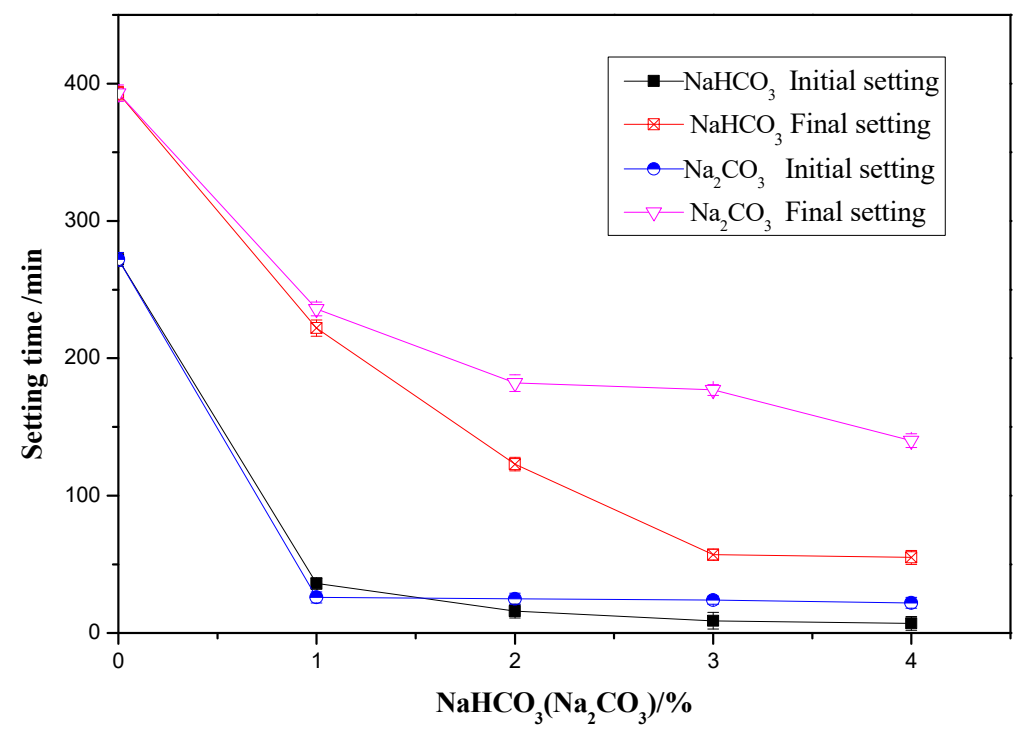

Figure 1. Effects of $\mathrm{NaHCO}_{3}$ and $\mathrm{Na}_{2} \mathrm{CO}_{3}$ on the setting time of OPC paste.

\subsection{Influence of $\mathrm{NaHCO}_{3} / \mathrm{Na}_{2} \mathrm{CO}_{3}$ on the Compressive Strength of OPC Paste}

The effect of $0 \%, 1 \%, 2 \%, 3 \%$, and $4 \%$ of $\mathrm{NaHCO}_{3}$ and $\mathrm{Na}_{2} \mathrm{CO}_{3}$ on the compressive strength of OPC paste specimen at the ages of 1, 7, and 28 days is shown in Figure 2. At the age of 1 day, with the increasing content of $\mathrm{NaHCO}_{3}$, the compressive strength of OPC paste increased initially and then decreased. The highest compressive strength happened in the mix with $3 \% \mathrm{NaHCO}_{3}$. The strength of the mix with $3 \% \mathrm{NaHCO}_{3}$ at the age of 1 day was $14 \%$ higher than that of the paste with no $\mathrm{NaHCO}_{3}$. At the age of 7 days, with the increase of $\mathrm{NaHCO}_{3}$, the compressive strength of OPC paste increased initially and then decreased with the highest strength happened in the mix with $1 \%$ $\mathrm{NaHCO}_{3}$. The strength of the mix with $1 \% \mathrm{NaHCO}_{3}$ at the age of 7 days was $6 \%$ higher than that of OPC. At 28 days, the compressive strength of cement paste deceased continuously with the increase of $\mathrm{NaHCO}_{3}$. It can be seen that below $1 \% \mathrm{NaHCO}_{3}$ can increase the early age strength but higher content of could decrease the later age strength significantly. This can be caused by the formation of $\mathrm{NaOH}[20]$, which is a strong alkali and could react with the silica sand in the paste specimen.

For the pastes with $\mathrm{Na}_{2} \mathrm{CO}_{3}$, the compressive strength at ages of 1 and 7 days firstly increased and then decreased with the increase of $\mathrm{Na}_{2} \mathrm{CO}_{3}$ content, and the paste with $1 \% \mathrm{Na}_{2} \mathrm{CO}_{3}$ had the highest compressive strength. The compressive strength of paste with $1 \% \mathrm{Na}_{2} \mathrm{CO}_{3}$ was $7.2 \%$ higher at age of 1 day and $7.7 \%$ higher at age of 7 days compared to that of OPC paste. Similarly to $\mathrm{NaHCO}_{3}$, the compressive strength of pastes with $\mathrm{Na}_{2} \mathrm{CO}_{3}$ at age of 28 days decreased continuously with the increase of $\mathrm{Na}_{2} \mathrm{CO}_{3}$. The reason could be that the formation of $\mathrm{NaOH}$ caused the decrease of compressive strength. From Figure 2 it can be seen that the $\mathrm{NaHCO}_{3}$ had the similar beneficial effect as $\mathrm{Na}_{2} \mathrm{CO}_{3}$ on the early age strength when the addition was below $1 \%$, but much worse effect than $\mathrm{Na}_{2} \mathrm{CO}_{3}$ on the strength development when the addition was above $1 \%$. 


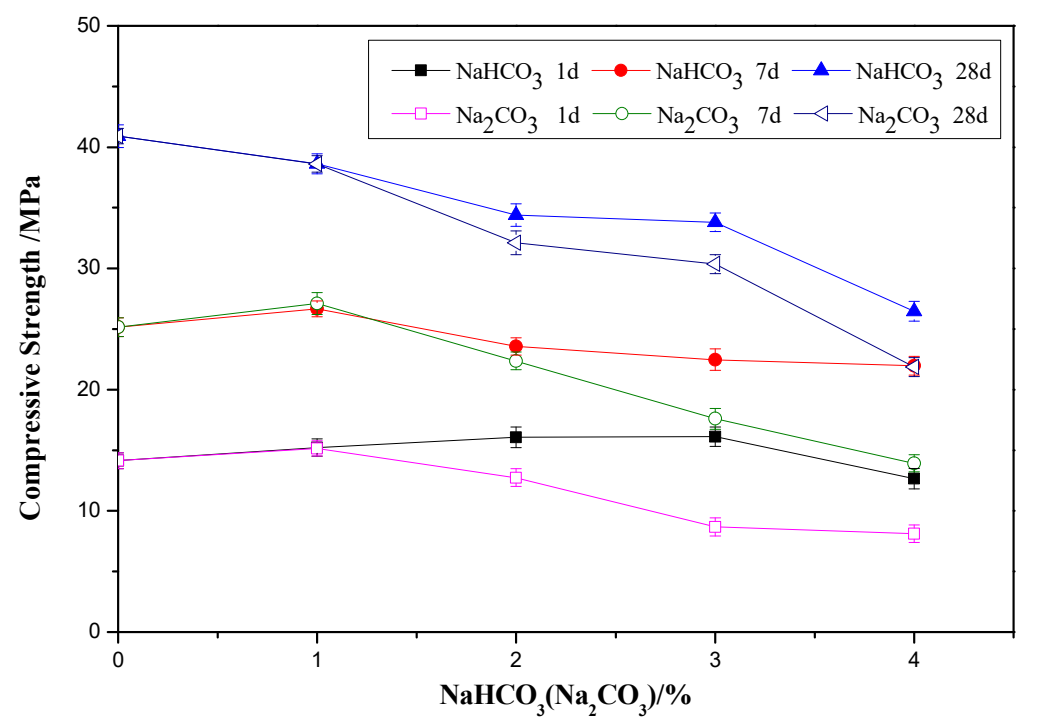

Figure 2. Effects of $\mathrm{NaHCO}_{3}$ and $\mathrm{Na}_{2} \mathrm{CO}_{3}$ on the compressive strength of $\mathrm{OPC}$ paste.

\subsection{Hydration Heat}

Figure 3 shows the hydration heat rate and accumulated hydration heat of the OPC pastes with $0 \%, 1 \%, 2 \%, 3 \%$, and $4 \% \mathrm{NaHCO}_{3}$. The first peak of hydration heat rate at around $0.05 \mathrm{~h}$ in Figure $3(\mathrm{a} 1)$ firstly decreased with the increase of $\mathrm{NaHCO}_{3}$ up to $2 \%$ and then increased with the further increase of $\mathrm{NaHCO}_{3}$ up to $4 \%$. The first peak associated with the formation ettringite (AFt) [34,35], and it is suggested that the addition of $1-2 \% \mathrm{NaHCO}_{3}$ refrained the formation of $\mathrm{AFt}$ in OPC paste but the further addition of $\mathrm{NaHCO}_{3}$ up to $4 \%$ accelerated the formation of AFt. The initial decrease of the $\mathrm{AFt}$ could be caused by the possible reaction or adhesion between the $\mathrm{NaHCO}_{3}$ and the aluminum phases, but the later increase of the $\mathrm{AFt}$ in the mix with $4 \% \mathrm{NaHCO}_{3}$ could be caused by the increased $\mathrm{CO}_{3}{ }^{2-}$ content [17].

Different from the trend of the first peak of hydration heat rate with content of $\mathrm{NaHCO}_{3}$, as shown in Figure 3(a2), the peak height of the second peak of the hydration heat rate at 8-15 $\mathrm{h}$ increased continuously with the increase of $\mathrm{NaHCO}_{3}$. The second peak associated with the hydration of $\mathrm{C}_{3} \mathrm{~S}$ and $\mathrm{C}_{2} \mathrm{~S}$ and the formation of C-S-H and portlandite. It can be seen that the addition of increased the peak height of the second peak and it was indicated that there could be more hydration of $C_{3} S$ and $C_{2} S$ at 8-15 $\mathrm{h}$ in the mix with more $\mathrm{NaHCO}_{3}$. However, the peak time of the second peak was delayed in the mixes with $1 \%$ and $2 \% \mathrm{NaHCO}_{3}$ but it was earlier in the mixes with $3 \%$ and $4 \% \mathrm{NaHCO}_{3}$ compared to the control group with no $\mathrm{NaHCO}_{3}$. It suggested that the addition of $\mathrm{NaHCO}_{3}$ up to $2 \%$ delayed the hydration of $\mathrm{C}_{3} \mathrm{~S}$ and $\mathrm{C}_{2} \mathrm{~S}$ but further increase of $\mathrm{NaHCO}_{3}$ up to $4 \%$ accelerated the hydration of $\mathrm{C}_{3} \mathrm{~S}$ and $\mathrm{C}_{2} \mathrm{~S}$ in the initial $24 \mathrm{~h}$.

The total accumulated hydration heat in the initial $24 \mathrm{~h}$ is shown in Figure $3 \mathrm{~b}$, and it shows that the difference between the total hydration heat of OPC paste and that of the mix with $1 \% \mathrm{NaHCO}_{3}$ was not significant, the mix with $2 \%$ had a much lower hydration heat than the OPC paste, but the mixes with $3 \%$ and $4 \%$ had a significantly higher total hydration heat than the OPC paste. This was mainly caused by the previously described delayed effect on the hydration heat in the mix with $2 \%$ $\mathrm{NaHCO}_{3}$ and the accelerated effect on the hydration heat in the mixes with $3 \%$ and $4 \% \mathrm{NaHCO}_{3}$. 


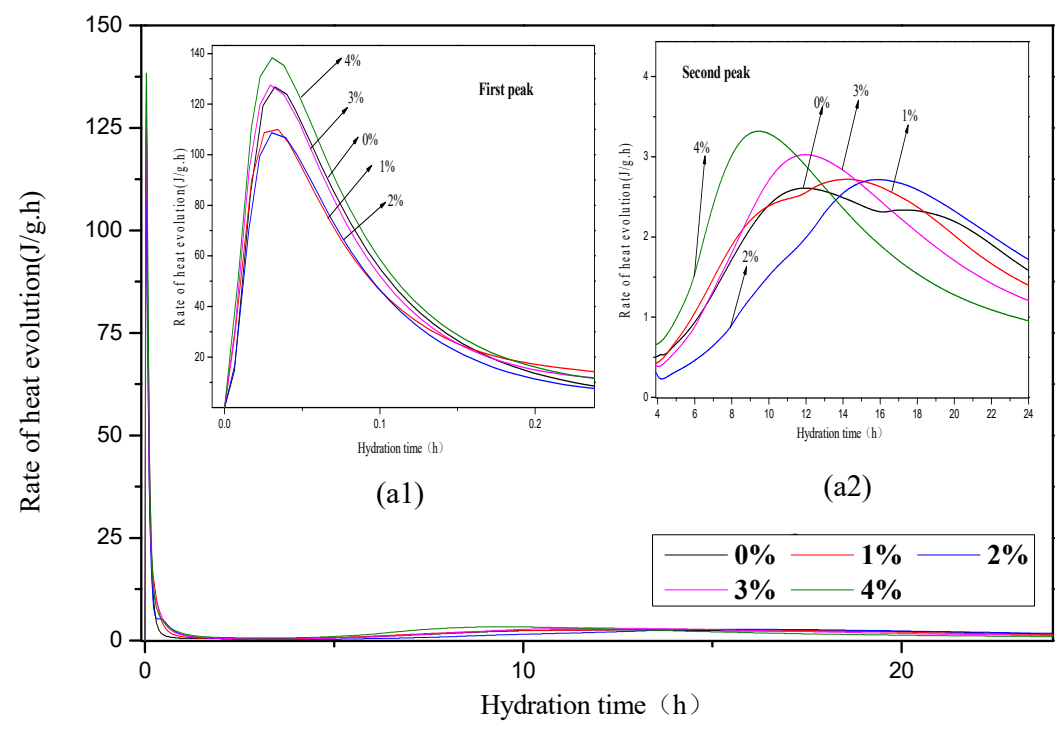

(a)

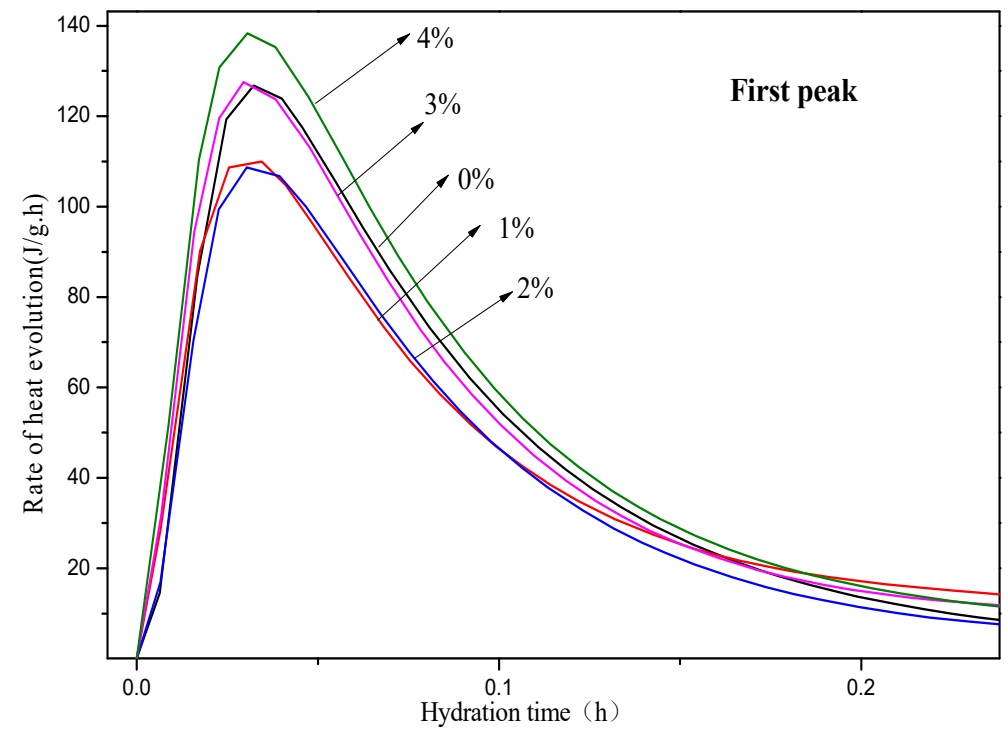

(a1)

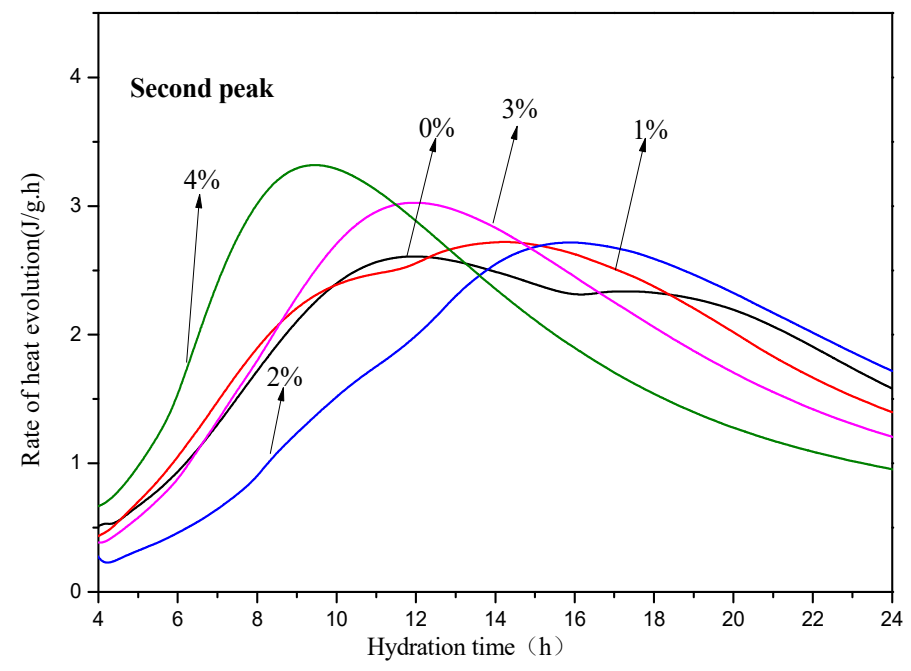

(a2)

Figure 3. Cont. 


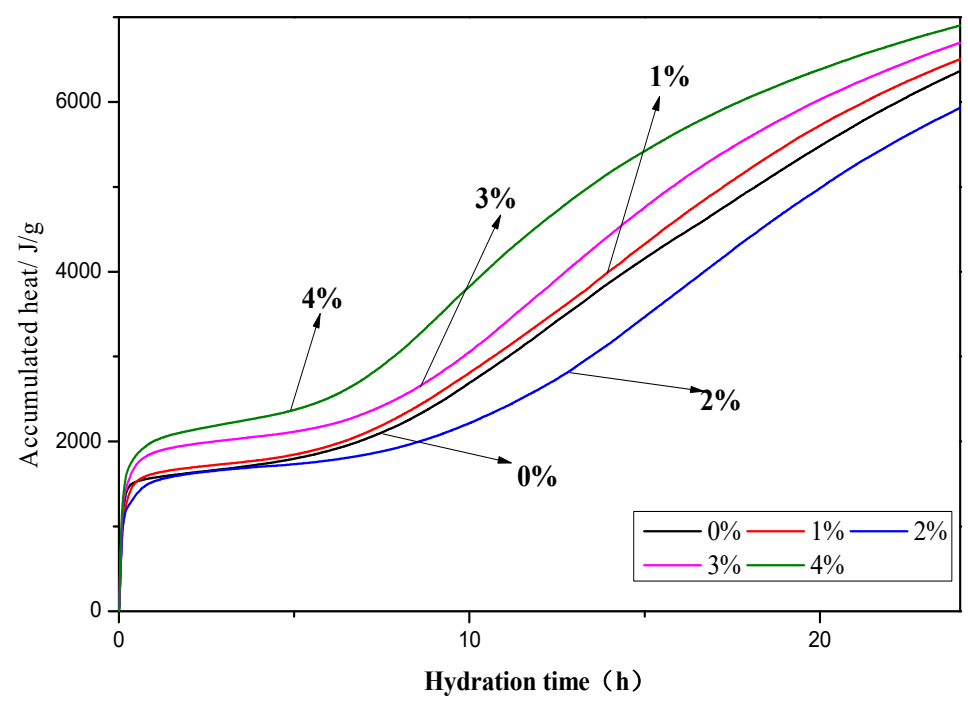

(b)

Figure 3. Hydration heat rate (a) and accumulated heat (b) of the pastes with different contents of $\mathrm{NaHCO}_{3}$.

The hydration heat rate and accumulated hydration heat of the mixes with $0 \%, 1 \%, 2 \%, 3 \%$, and $4 \% \mathrm{Na}_{2} \mathrm{CO}_{3}$ are shown in Figure 4. The results show that the mixes with $\mathrm{Na}_{2} \mathrm{CO}_{3}$ had a higher first peak height of the hydration heat rate, as in Figure 4(a1), than the OPC paste with no $\mathrm{Na}_{2} \mathrm{CO}_{3}$. The highest first peak height happened in the mix with $3 \% \mathrm{Na}_{2} \mathrm{CO}_{3}$ and there was a slightly decrease of the peak height in the mix with $4 \% \mathrm{Na}_{2} \mathrm{CO}_{3}$. It is indicated that the addition of $\mathrm{Na}_{2} \mathrm{CO}_{3}$ accelerated the hydration of $\mathrm{C}_{3} \mathrm{~A}$ and the formation of $\mathrm{AFt}$.

As for the second peak, in Figure 4(a2), the addition of $\mathrm{Na}_{2} \mathrm{CO}_{3}$ increased the peak height and accelerated the peak time compared to the OPC paste with no $\mathrm{Na}_{2} \mathrm{CO}_{3}$. It suggested that the $\mathrm{Na}_{2} \mathrm{CO}_{3}$ accelerated and increased the hydration of $\mathrm{C}_{3} \mathrm{~S}$ and $\mathrm{C}_{2} \mathrm{~S}$. This agrees with the findings in literature [33]. There was a shoulder peak at around $18 \mathrm{~h}$ after the second peak in the control group, which was cause by the secondary formation of AFt [36], but this shoulder peak did not appear in any mix with $\mathrm{Na}_{2} \mathrm{CO}_{3}$. This suggested that, in the mixes with $\mathrm{Na}_{2} \mathrm{CO}_{3}$, the initial accelerated formation of AFt in the first peak might consumed most of the $\mathrm{C}_{3} \mathrm{~A}$ and formation of most $\mathrm{AFt}$ was finished at that time.

The accumulated hydration heat of the mixes with different contents of $\mathrm{Na}_{2} \mathrm{CO}_{3}$ is shown in Figure $4 \mathrm{~b}$. It can be seen that the mix with $\mathrm{Na}_{2} \mathrm{CO}_{3}$ had a much higher accumulated hydration heat compared to the control group. At 5-10 h, the mix with $4 \% \mathrm{Na}_{2} \mathrm{CO}_{3}$ had the highest accumulated hydration heat and the higher content of $\mathrm{Na}_{2} \mathrm{CO}_{3}$ caused a higher accumulated hydration heat. At the end of $24 \mathrm{~h}$, the mix with $1 \% \mathrm{Na}_{2} \mathrm{CO}_{3}$ had the highest total hydration heat, followed by the mixes with $3 \%, 2 \%, 4 \%$, and $0 \% \mathrm{Na}_{2} \mathrm{CO}_{3}$. After $15 \mathrm{~h}$, the increase rate of the accumulated hydration heat in the mixes with $3 \%$ and $4 \% \mathrm{Na}_{2} \mathrm{CO}_{3}$ decreased obviously compared to the mixes with $1 \%$ and $2 \% \mathrm{Na}_{2} \mathrm{CO}_{3}$. There was a tendency that the total hydration heat of the mixes with $3 \%$ and $4 \% \mathrm{Na}_{2} \mathrm{CO}_{3}$ could be lower than the control group in the long term. 


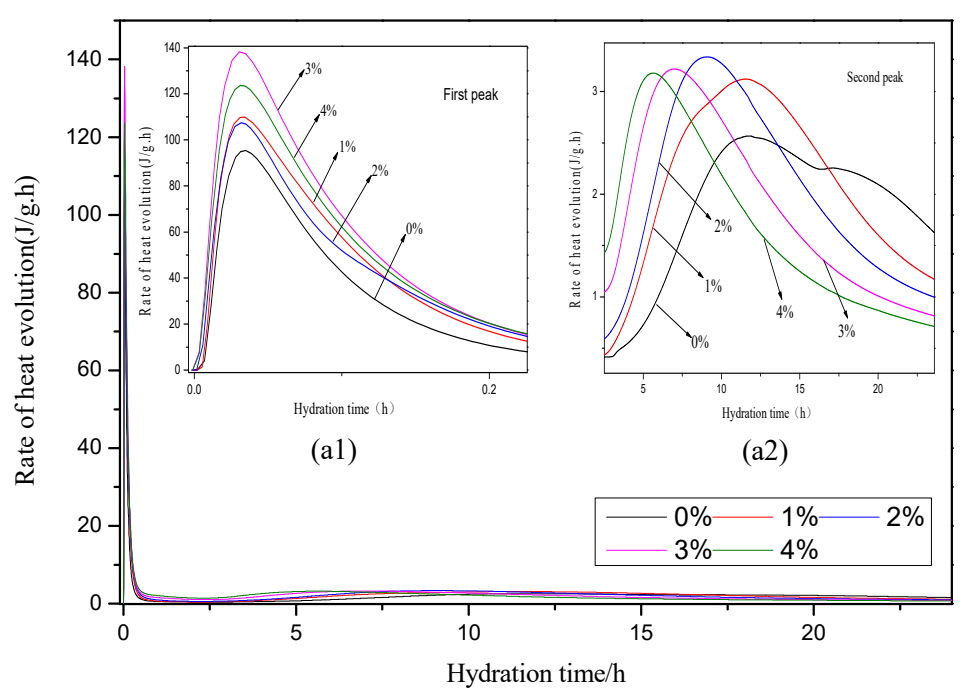

(a)

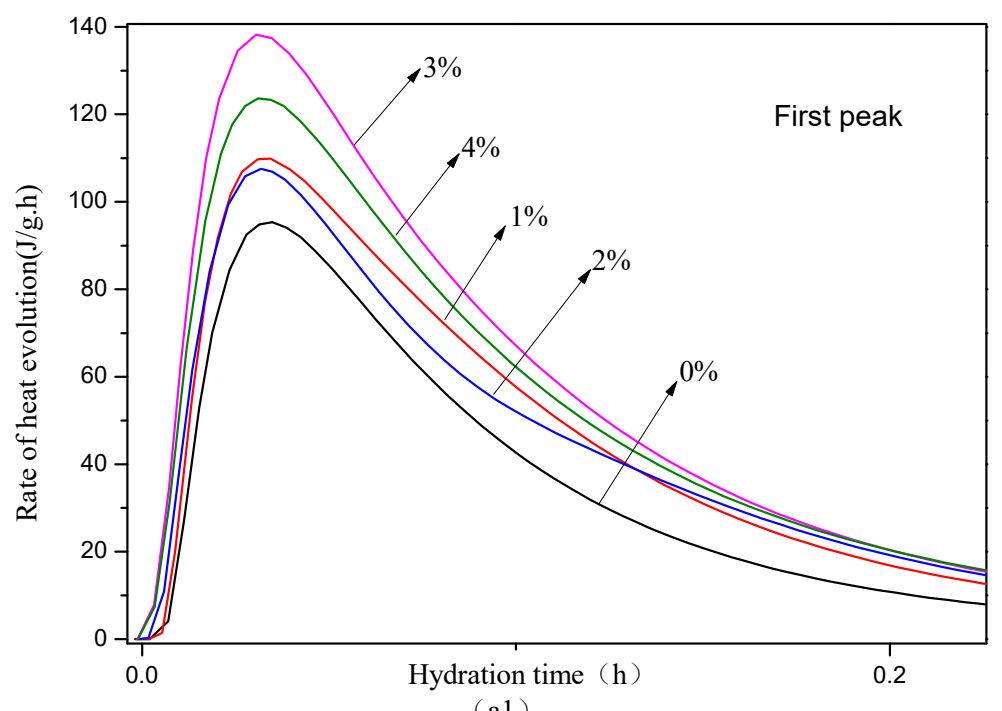

(a1)

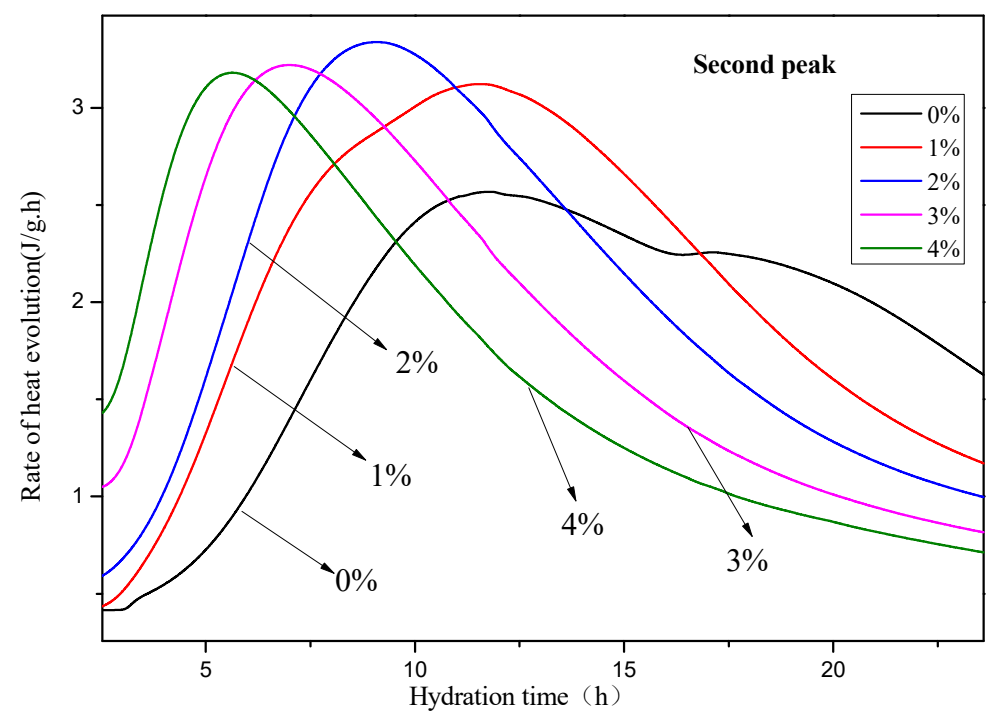

(a2)

Figure 4. Cont. 


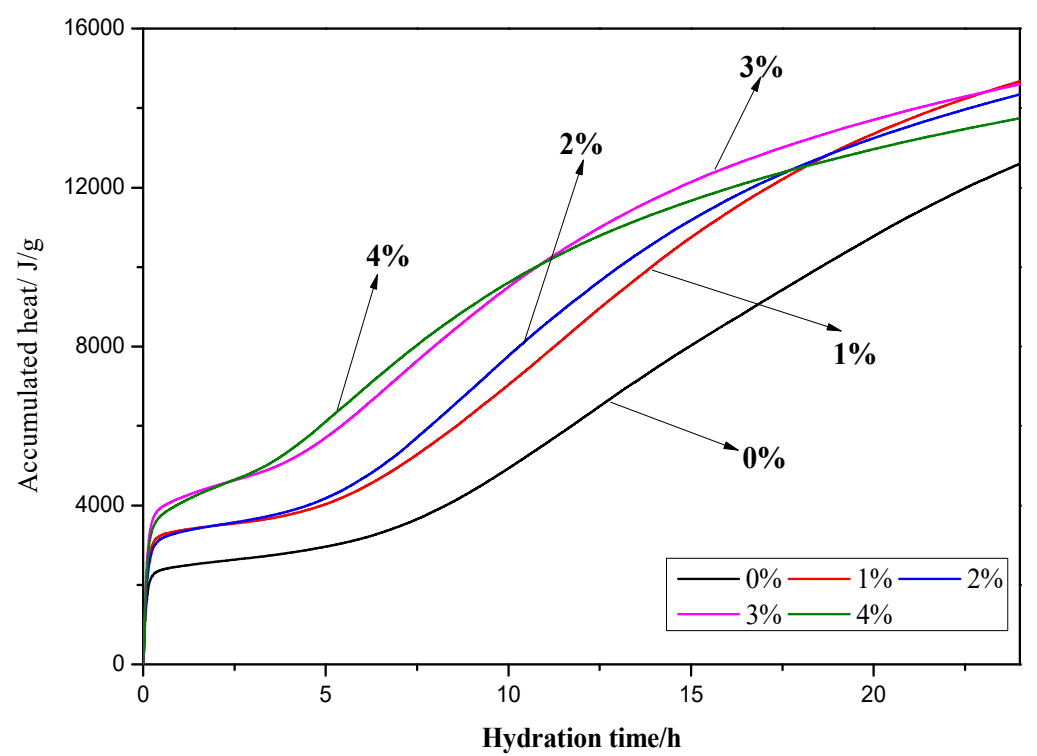

(b)

Figure 4. Hydration heat rate (a) and accumulated heat (b) of the pastes with different contents of $\mathrm{Na}_{2} \mathrm{CO}_{3}$.

\subsection{TG-DTA Results}

The TG-DTA results of the mixes with $0 \%, 1 \%, 2 \%, 3 \%$, and $4 \% \mathrm{NaHCO}_{3}$ are shown in Figure 5 . There were three main DTA peaks at around $100{ }^{\circ} \mathrm{C}, 460{ }^{\circ} \mathrm{C}$, and $700^{\circ} \mathrm{C}$, which indicated the composition of $\mathrm{AFt}$, portlandite and $\mathrm{CaCO}_{3}$ respectively. At the age of 1 day, the weight loss at the peak of AFt was $2.6 \%, 2.9 \%, 2.7 \%, 2.6 \%$, and $3.1 \%$ in the mix with $0 \%, 1 \%, 2 \%, 3 \%$, and $4 \% \mathrm{NaHCO}_{3}$ respectively. The weight loss at the peak of portlandite was $2.0 \%, 1.6 \%, 1.5 \%, 1.2 \%$, and $1.0 \%$ in the mix with $0 \%, 1 \%, 2 \%, 3 \%$, and $4 \% \mathrm{NaHCO}_{3}$ respectively. The weight loss at the peak of $\mathrm{CaCO}_{3}$ was $3.5 \%, 3.9 \%, 4.0 \%, 4.8 \%$, and $4.7 \%$ in the mix with $0 \%, 1 \%, 2 \%, 3 \%$, and $4 \% \mathrm{NaHCO}_{3}$ respectively. It can be seen that the addition of $\mathrm{NaHCO}_{3}$ increased the formation of $\mathrm{AFt}$ and $\mathrm{CaCO}_{3}$ at the age of 1 day but decreased the portlandite. At the age of 7 and 28 days, the weight losses at the peaks of AFt, portlandite and $\mathrm{CaCO}_{3}$ showed similar trend as that age of 1 day. It can be seen that the addition of $\mathrm{NaHCO}_{3}$ increased the formation of AFt and $\mathrm{CaCO}_{3}$ and decreased the portlandite at all the ages.

Figure 6 shows the TG-DTA results of the mixes with $0 \%, 1 \%, 2 \%, 3 \%$, and $4 \% \mathrm{Na}_{2} \mathrm{CO}_{3}$ at the ages of 1,7 , and 28 days. At the age of 1 day, the weight loss at the peak of AFt was $2.6 \%, 2.6 \%, 3.0 \%$, $2.8 \%$, and $3.0 \%$ in the mix with $0 \%, 1 \%, 2 \%, 3 \%$, and $4 \% \mathrm{Na}_{2} \mathrm{CO}_{3}$ respectively. The weight loss at the peak of portlandite was $2.0 \%, 1.6 \%, 1.4 \%, 1.1 \%$, and $0.9 \%$ in the mix with $0 \%, 1 \%, 2 \%, 3 \%$, and $4 \%$ $\mathrm{Na}_{2} \mathrm{CO}_{3}$ respectively. The weight loss at the peak of $\mathrm{CaCO}_{3}$ was $3.5 \%, 3.9 \%, 4.0 \%, 4.8 \%$, and $4.7 \%$ in the mix with $0 \%, 1 \%, 2 \%, 3 \%$, and $4 \% \mathrm{Na}_{2} \mathrm{CO}_{3}$ respectively. It can be seen that, similar as the $\mathrm{NaHCO}_{3}$, the addition of $\mathrm{Na}_{2} \mathrm{CO}_{3}$ increased the formation of $\mathrm{AFt}$ and $\mathrm{CaCO}_{3}$ and decreased the portlandite at the age of 1 day. This trend was similar at the ages of 7 and 28 days.

These results showed that the influence of $\mathrm{NaHCO}_{3}$ on the formation of $\mathrm{AFt}$, portlandite and $\mathrm{CaCO}_{3}$ was similar as $\mathrm{Na}_{2} \mathrm{CO}_{3}$. The mix with the highest amount of $\mathrm{NaHCO}_{3}$ or $\mathrm{Na}_{2} \mathrm{CO}_{3}$ had the highest amount of $\mathrm{AFt}$ and $\mathrm{CaCO}_{3}$ but the lowest amount of portlandite. As can be seen from Figures 5 and 6, the addition of $\mathrm{NaHCO}_{3}$ or $\mathrm{Na}_{2} \mathrm{CO}_{3}$ made the overall weight loss of the blended paste higher than the control group at the age of 1 and 7 days but the lower than the control group at the age of 28 days. 


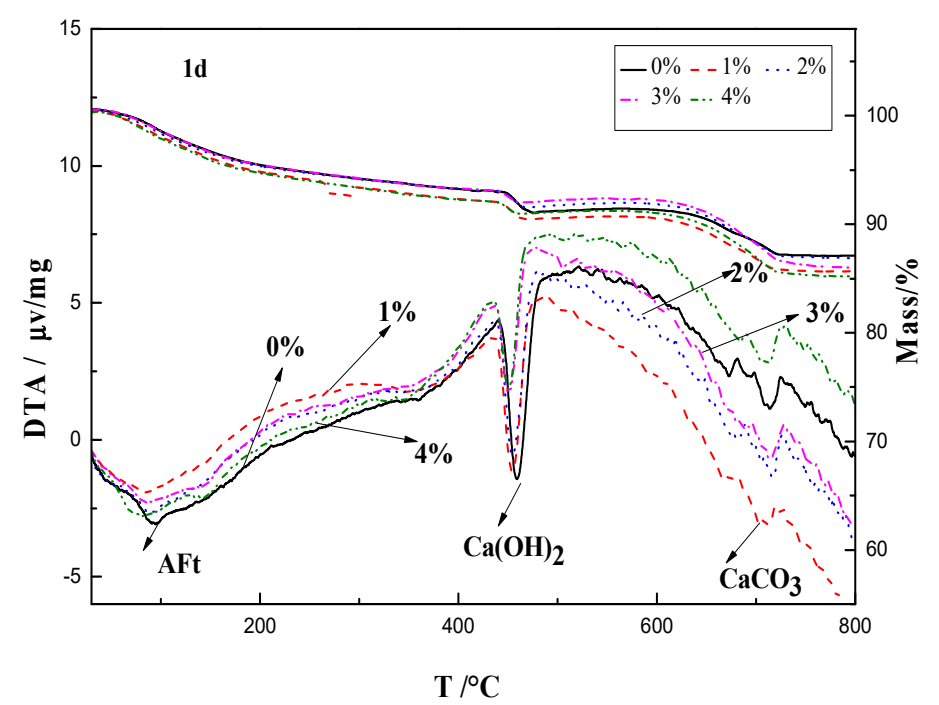

(a) 1 day

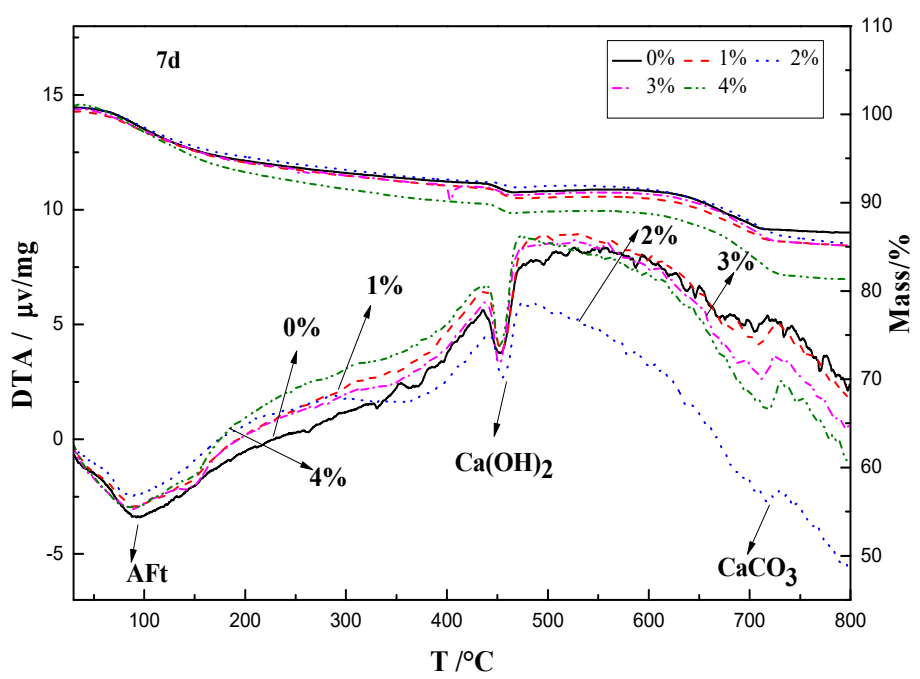

(b) 7 days

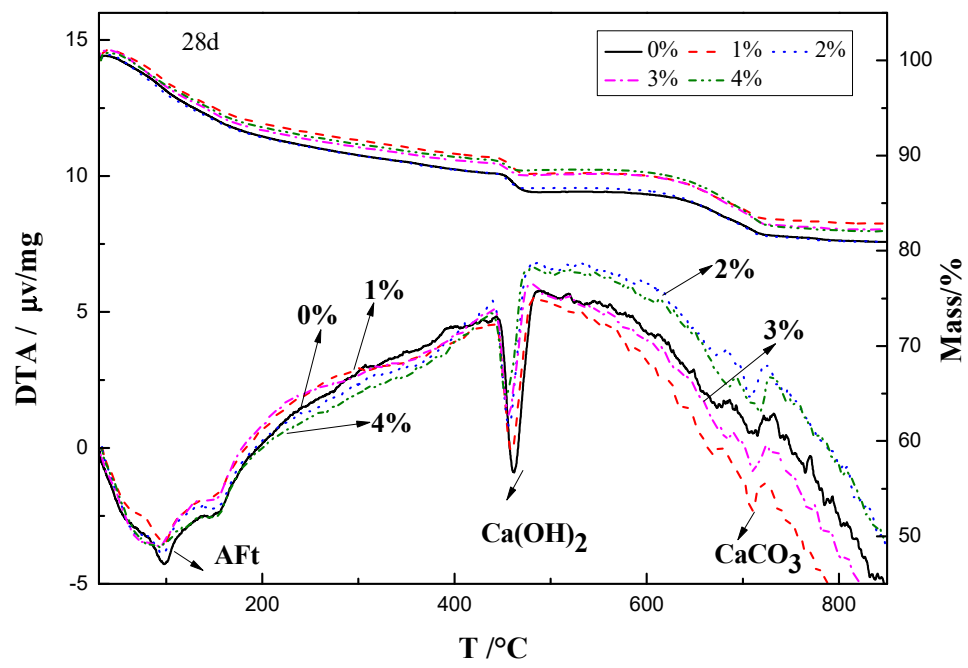

(c) 28 days

Figure 5. TG-DTA results of the pastes with different contents of $\mathrm{NaHCO}_{3}$ at ages of (a) $1,(\mathbf{b}) 7$, and (c) 28 days. 


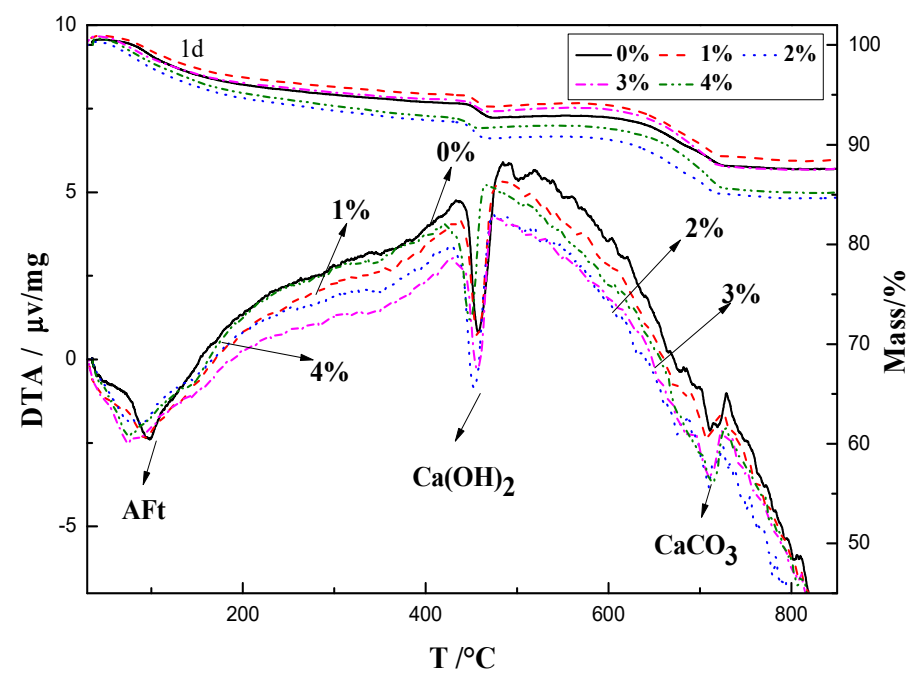

(a) 1 day

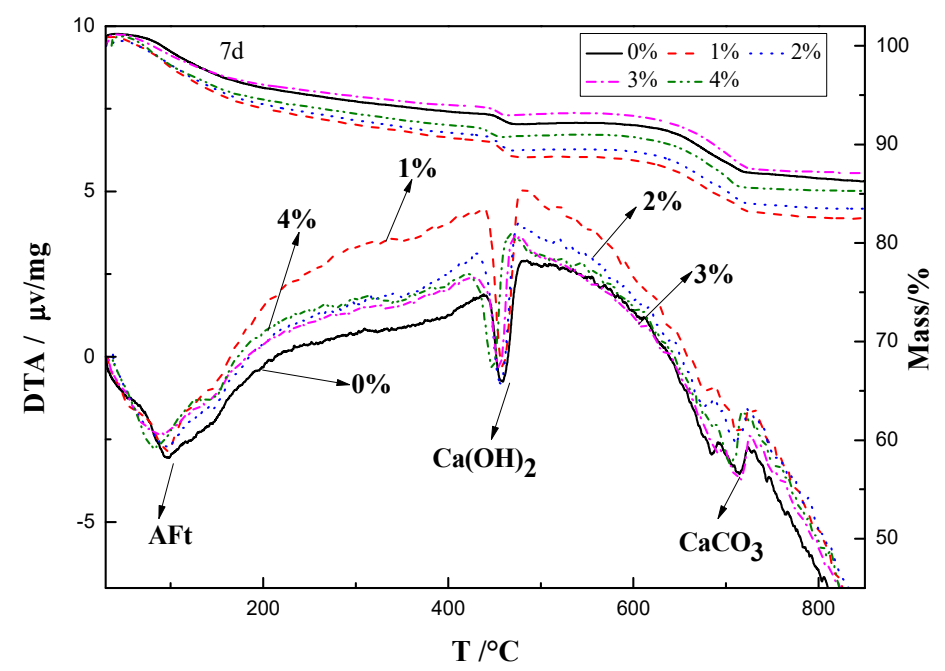

(b) 7 days

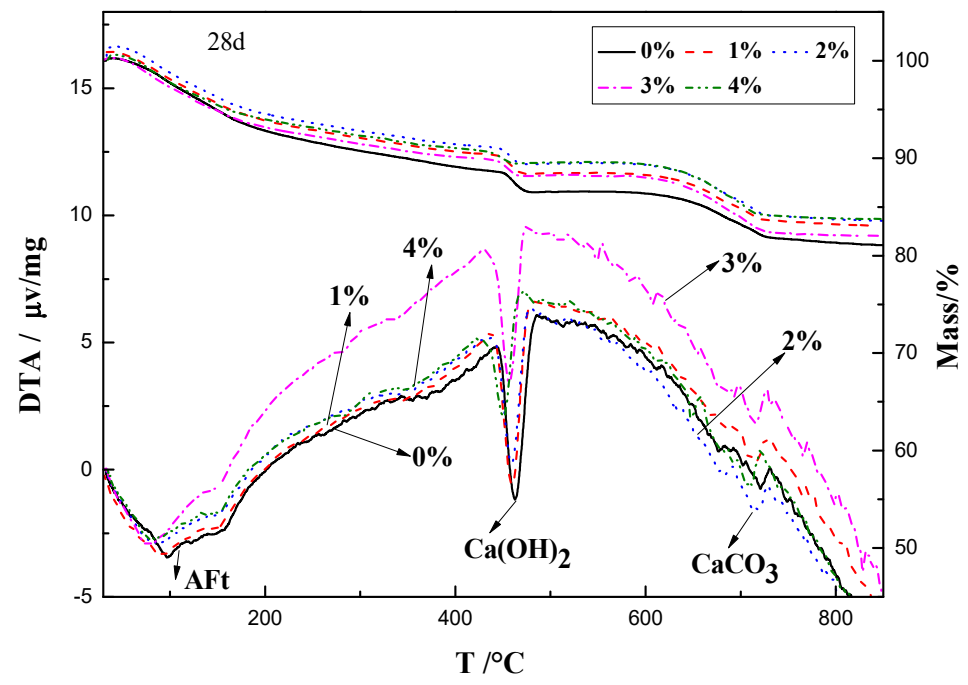

(c) 28 days

Figure 6. TG-DTA results of the pastes with different contents of $\mathrm{Na}_{2} \mathrm{CO}_{3}$ at ages of (a) 1, (b) 7, and (c) 28 days. 


\subsection{XRD Results}

The XRD results of the pastes with $0 \%, 1 \%, 2 \%, 3 \%$, and $4 \% \mathrm{NaHCO}_{3}$ at the ages of 1,7 , and 28 days are shown in Figure 7. It can be seen that, at the age of 1 day, the peaks of $\mathrm{Ca}(\mathrm{OH})_{2}$ at $2 \theta=34^{\circ}$ and $47^{\circ}$ decreased with the increase of $\mathrm{NaHCO}_{3}$. At the ages of 7 and 28 days, the peaks of portlandite changed in the same way as that in 1 day, besides, the peak of C-S- $\mathrm{H}$ and $\mathrm{CaCO}_{3}$ at $2 \theta=29^{\circ}$ increased with the increase of $\mathrm{NaHCO}_{3}$. These results all agree with the previously reported findings in the TG-DTA results. The change of AFt in the XRD spectrum was not obvious for the mixes with different contents of $\mathrm{NaHCO}_{3}$.

Figure 8 shows the $\mathrm{XRD}$ results of the pastes with $0 \%, 1 \%, 2 \%, 3 \%$, and $4 \% \mathrm{Na}_{2} \mathrm{CO}_{3}$ at the ages of 1,7 , and 28 days. The results show that the peaks of $\mathrm{C}-\mathrm{S}-\mathrm{H}$ and $\mathrm{CaCO}_{3}$ increased with the increase of $\mathrm{Na}_{2} \mathrm{CO}_{3}$ content at all ages, at the same time, the portlandite decreased gradually with the increase of $\mathrm{Na}_{2} \mathrm{CO}_{3}$ content. This again agrees with the findings in TG-DTA results.

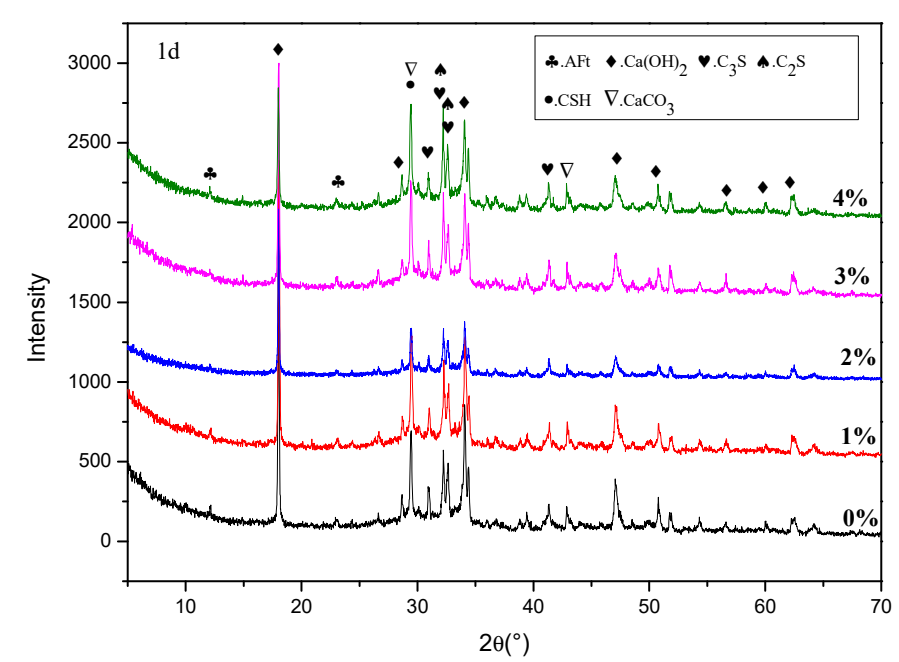

(a) 1 day

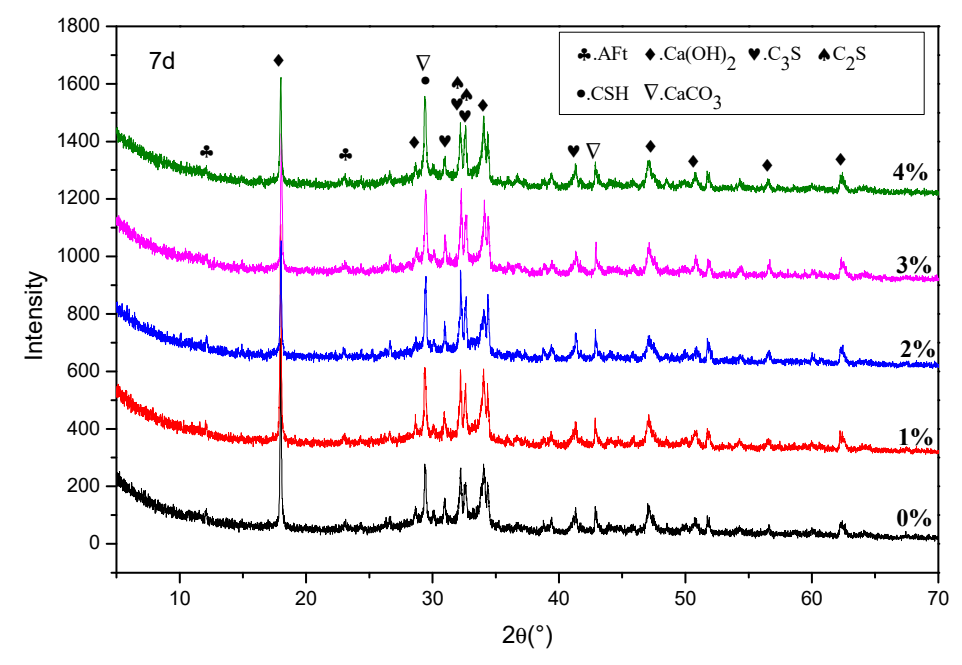

(b) 7 days

Figure 7. Cont. 


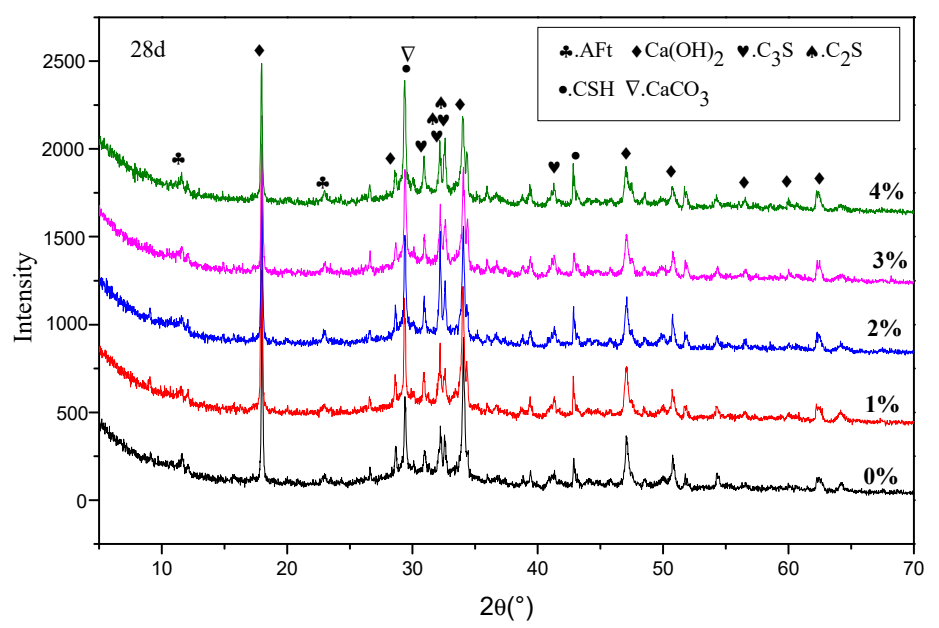

(c) 28 days

Figure 7. XRD spectrum results of the mixes with different contents of $\mathrm{NaHCO}_{3}$ at ages of (a) 1 , (b) 7 , and (c) 28 days.

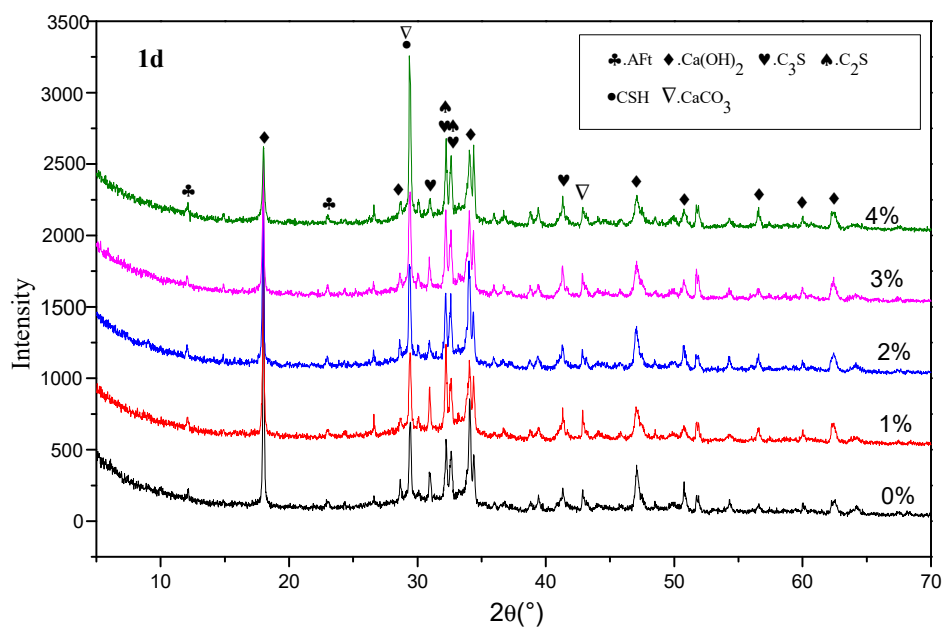

(a) 1 day

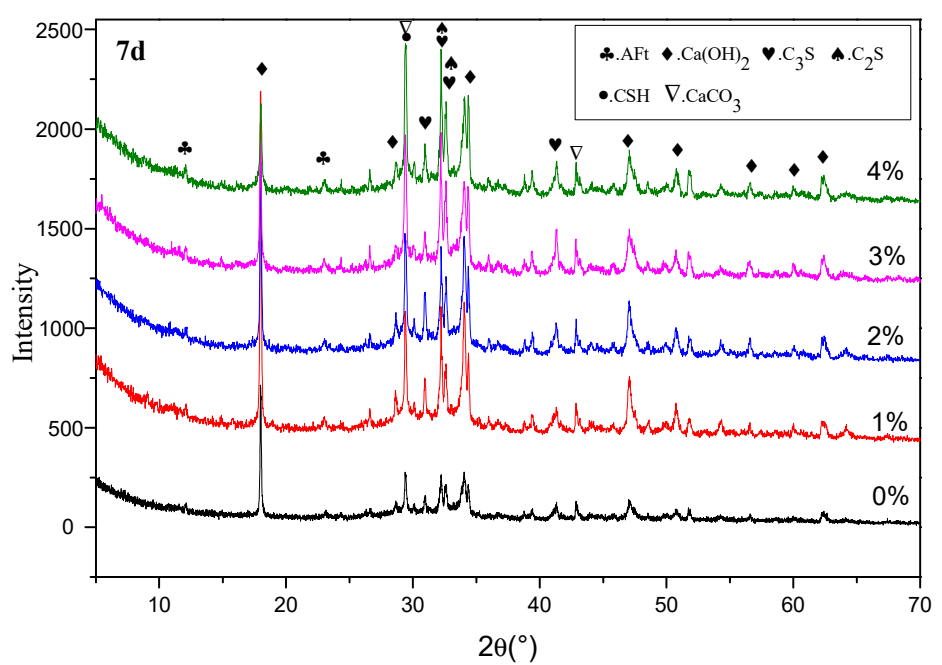

(b) 7 days

Figure 8. Cont. 


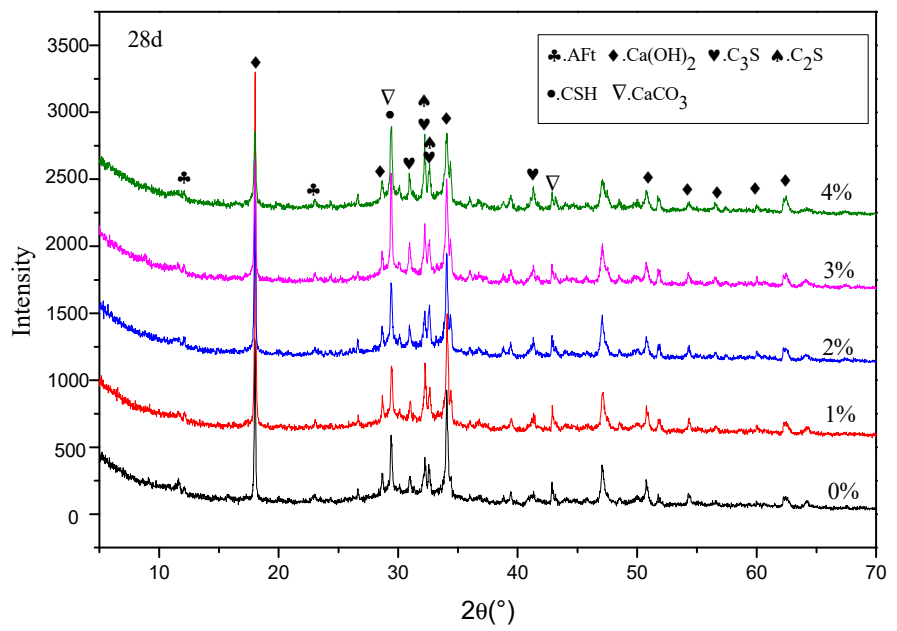

(c) 28 days

Figure 8. XRD spectrum results of the mixes with different contents of $\mathrm{Na}_{2} \mathrm{CO}_{3}$ at ages of (a) 1 , (b) 7 , and (c) 28 days.

\subsection{SEM Results}

The SEM results of the pastes with $0 \%, 1 \%, 2 \%, 3 \%$, and $4 \% \mathrm{NaHCO}_{3}$ at the ages of 1,7 , and 28 days are shown in Figure 9. At the age of 1 day, it can be seen that the amount of needle-shaped ettringite in the mixes with $\mathrm{NaHCO}_{3}$ was higher than that in the pure OPC paste. The microstructure of the C-S-H gel in the mixes with 1\%,2\%, and 3\% was denser than that in the pure OPC paste, but the C-S-H gel in the mix with $4 \%$ was a bit loose compared to the other groups. These agrees with the changing trend of the compressive strength with $\mathrm{NaHCO}_{3}$ at 1 day in Figure 2. At the age of 7 days, the mix with $1 \%$ $\mathrm{NaHCO}_{3}$ had more ettringite and denser C-S-H gel than the pure OPC paste, but further increase of $\mathrm{NaHCO}_{3}$ made the C-S-H gel become loose although the amount of ettringite was increased. At the age of 28 days, the ettringite in the mixes with $\mathrm{NaHCO}_{3}$ was still higher than that in pure OPC paste but the C-S-H gel in the mixes with $\mathrm{NaHCO}_{3}$ was looser than that in pure OPC paste. These agree with the results of XRD and compressive strength.

Figure 10 shows the SEM images of the mixes with $0 \%, 1 \%, 2 \%, 3 \%$, and $4 \% \mathrm{Na}_{2} \mathrm{CO}_{3}$ at the ages of 1,7 , and 28 days. At the age of 1 and 7 days, the mix with $1 \% \mathrm{Na}_{2} \mathrm{CO}_{3}$ had more ettringite and a denser C-S-H structure than the pure OPC paste. The mixes with $2-4 \%$ had more ettringite but a worse $\mathrm{C}-\mathrm{S}-\mathrm{H}$ gel structure than the pure OPC paste. At the age of 28 days, the C-S-H gel became worse with the increase of $\mathrm{Na}_{2} \mathrm{CO}_{3}$ content compared to the OPC paste with no $\mathrm{Na}_{2} \mathrm{CO}_{3}$. These results agree with the compressive strength results as shown in Figure 2. It could be indicated that the early age strength at 1 day was mainly influenced by both ettringite and C-S-H gel, and the later age strength, such as 28 days, was mainly influenced by C-S-H gel structure.

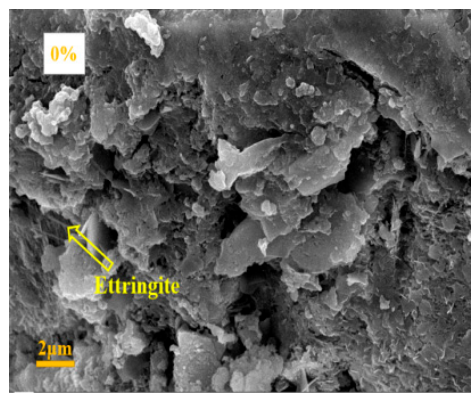

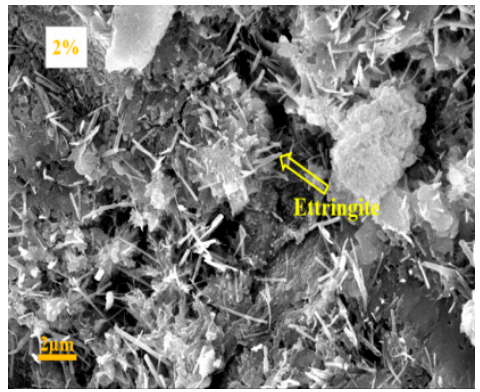

Figure 9. Cont. 

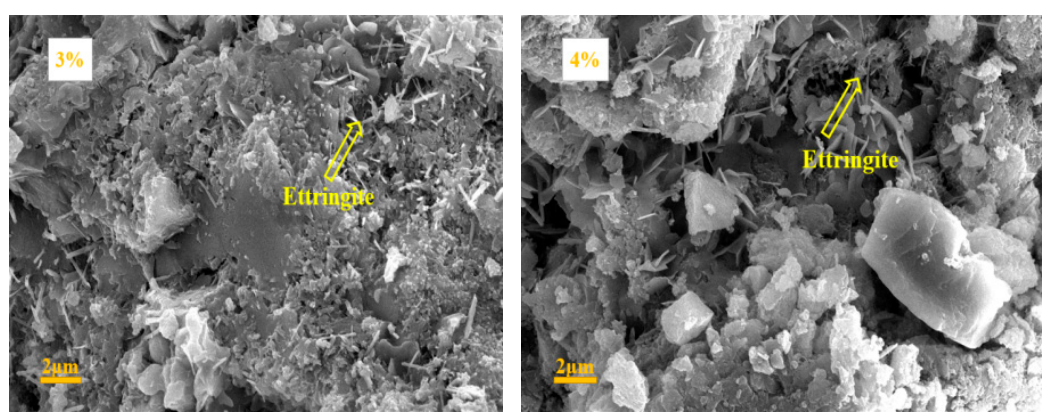

(a) 1 day
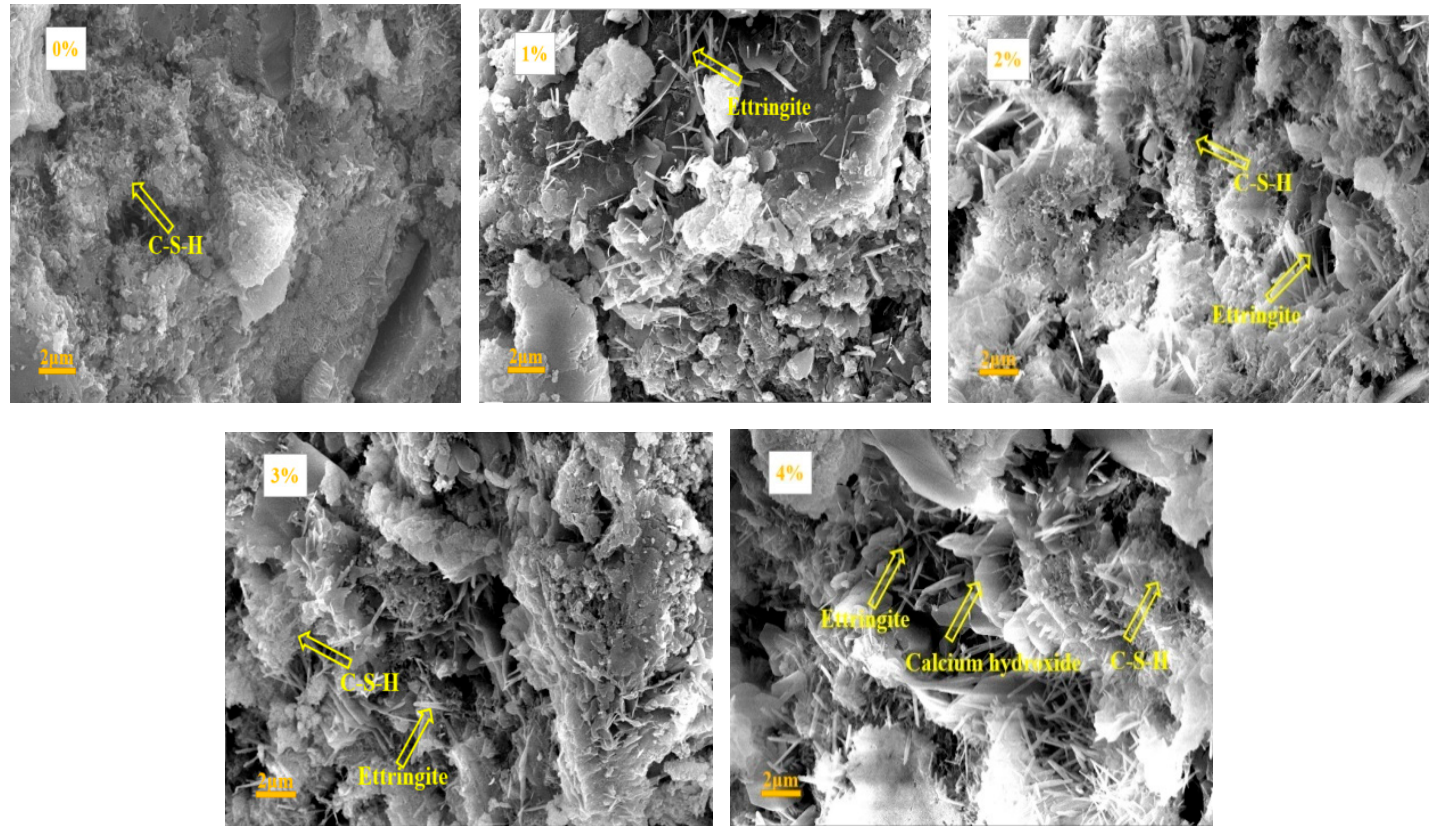

(b) 7 days
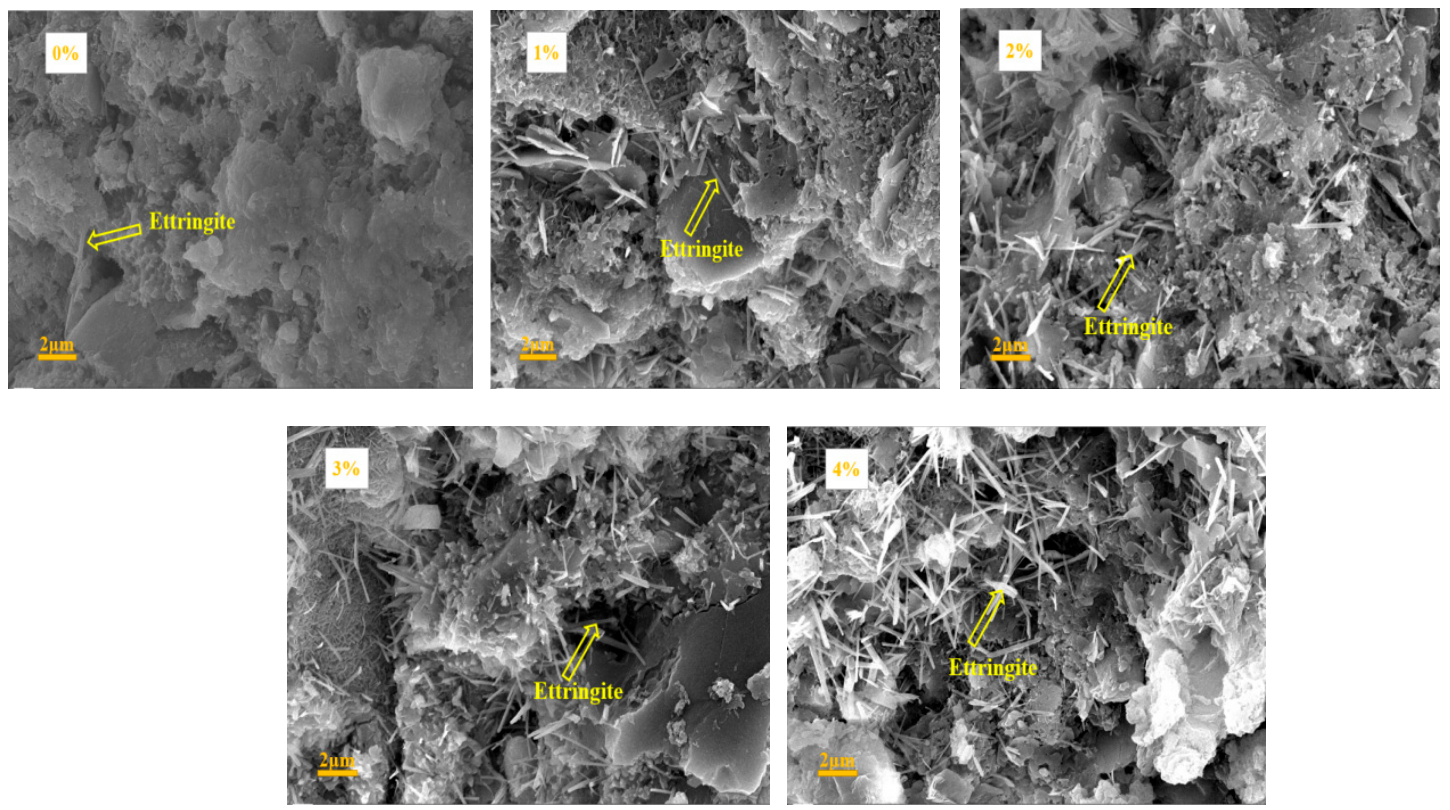

(c) 28 days

Figure 9. SEM results of the mixes with different contents of $\mathrm{NaHCO}_{3}$ at ages of (a) 1, (b) 7, and (c) 28 days. 

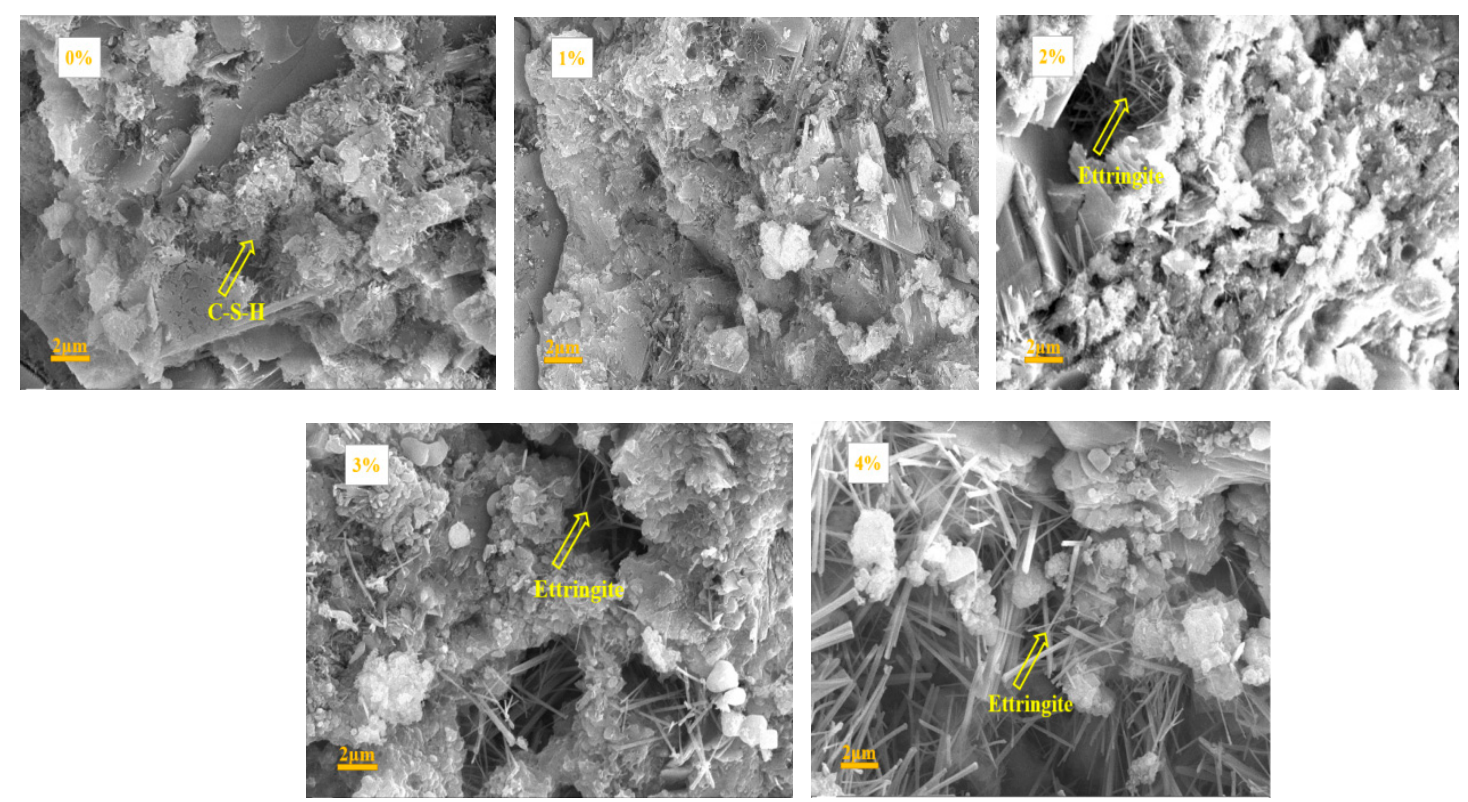

(a) 1 day
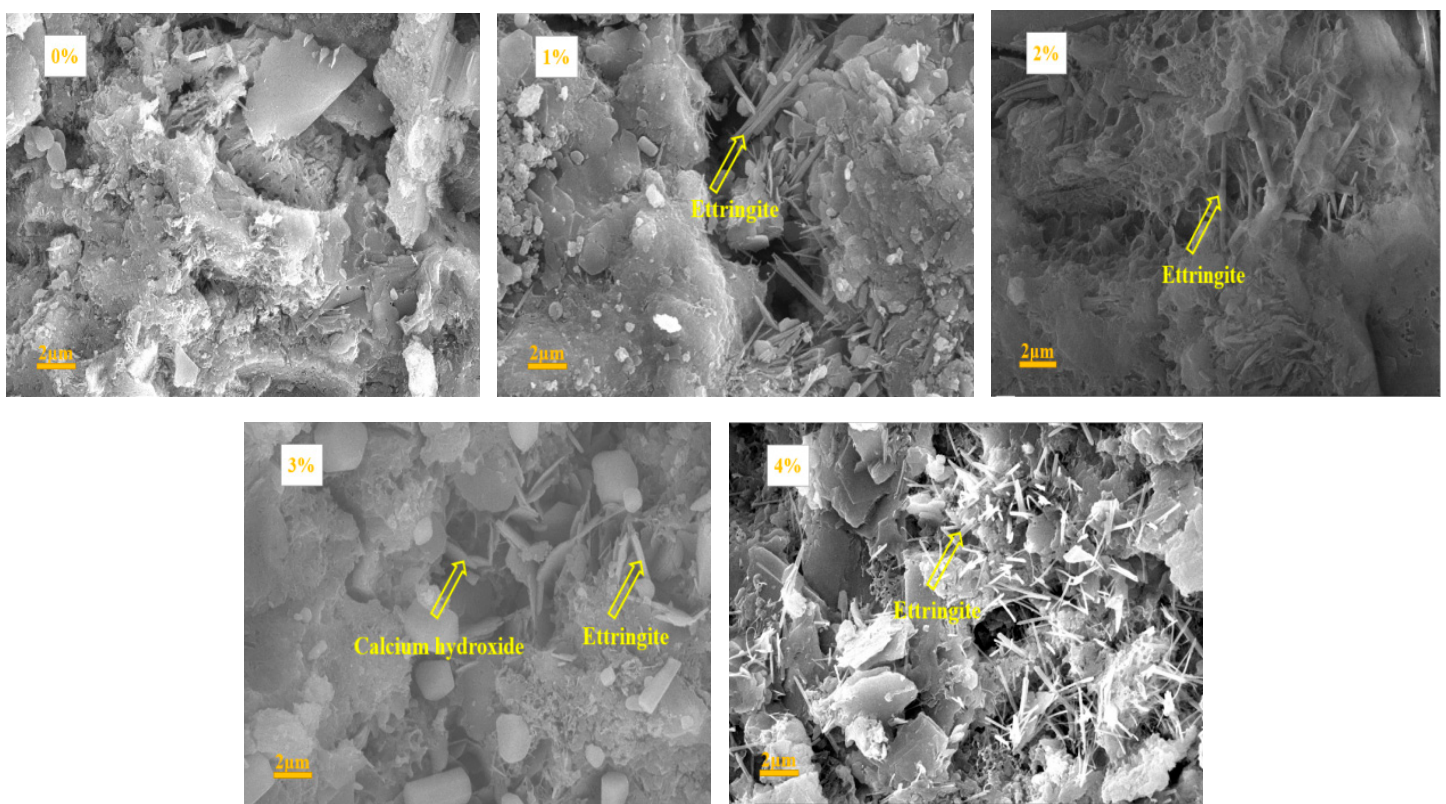

(b) 7 days
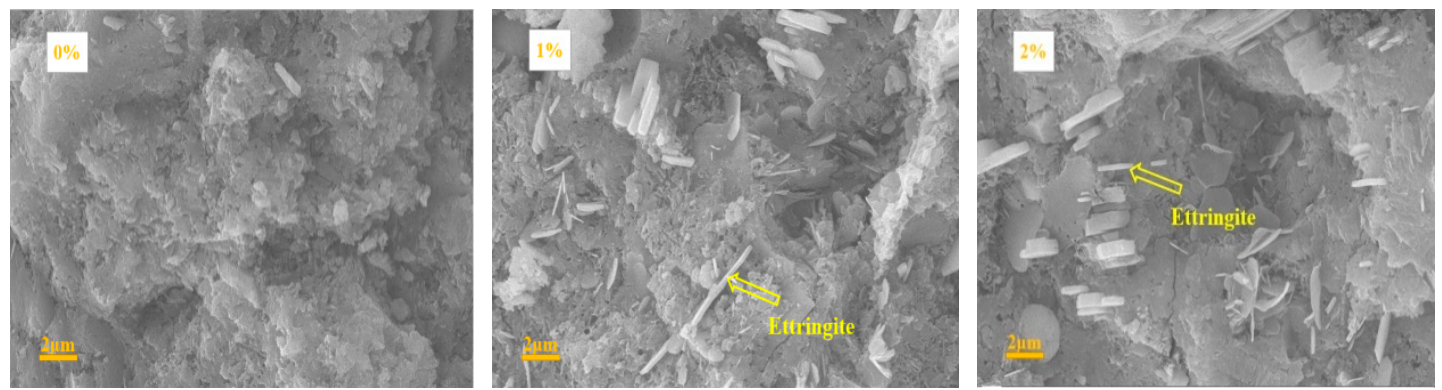

Figure 10. Cont. 


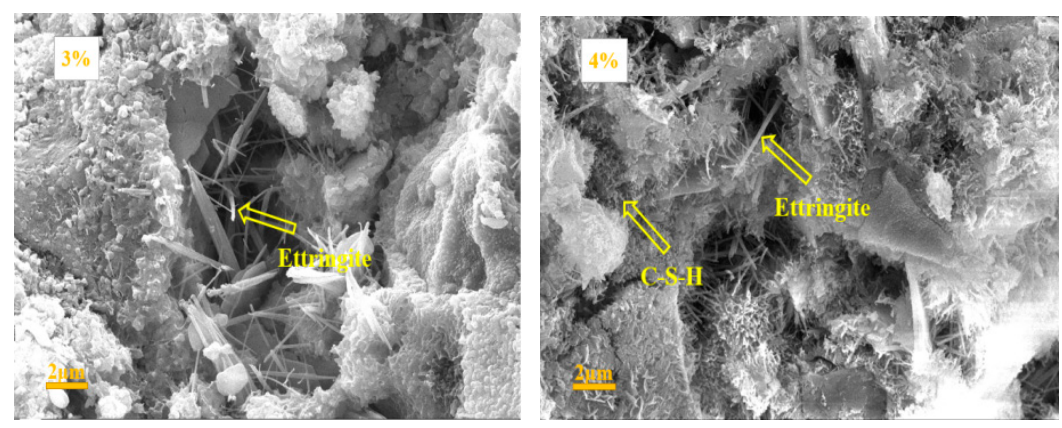

(c) 28 days

Figure 10. SEM results of the mixes with different contents of $\mathrm{Na}_{2} \mathrm{CO}_{3}$ at ages of (a) 1, (b) 7, and (c) 28 days.

\section{Discussion}

\subsection{Influence of $\mathrm{Na}_{2} \mathrm{CO}_{3} / \mathrm{NaHCO}_{3}$ on the PH of OPC Paste}

It is known that the both $\mathrm{Na}_{2} \mathrm{CO}_{3}$ and $\mathrm{NaHCO}_{3}$ are soluble and their main difference is that the $\mathrm{Na}_{2} \mathrm{CO}_{3}$ dissolves into $\mathrm{Na}^{+}$and $\mathrm{CO}_{3}{ }^{2-}$ and the $\mathrm{NaHCO}_{3}$ dissolves into $\mathrm{Na}^{+}$and $\mathrm{HCO}_{3}{ }^{-}$in water as shown in Equations (1) and (2). Solutions of $\mathrm{Na}_{2} \mathrm{CO}_{3}$ or $\mathrm{NaHCO}_{3}$ have a $\mathrm{PH}>7$, and the $\mathrm{PH}$ of $\mathrm{Na}_{2} \mathrm{CO}_{3}$ solution is higher than that of bicarbonate solution when the same content of the two are added. For example, under the same concentration $1 \mathrm{mmol} / \mathrm{L}\left(25^{\circ} \mathrm{C}\right.$ and $\left.1 \mathrm{~atm}\right)$, the $\mathrm{pH}$ values of $\mathrm{Na}_{2} \mathrm{CO}_{3}$ and $\mathrm{NaHCO}_{3}$ solutions are 10.52 and 8.27 respectively. When they are added in cement paste, both of them can react with the portlandite, which is a hydration product of cement, and form $\mathrm{CaCO}_{3}$, as Equations (3) and (4). Cement slurry was prepared for $\mathrm{pH}$ measurements with a water-cement ratio of 0.5 , a water reducing agent of $0.5 \%$, and $\mathrm{Na}_{2} \mathrm{CO}_{3}$ and $\mathrm{NaHCO}_{3}$ of $0 \%, 1 \%, 2 \%, 3 \%$, and $4 \%$. The $\mathrm{pH}$ meter was initially calibrated with a neutral solution $(\mathrm{pH}=7)$ and then with an alkaline solution with a known $\mathrm{pH}$. After the calibration is completed, the electrode of the $\mathrm{pH}$ meter was immersed into the cement slurry and the slurry was gently vibrated to reach a uniform state during the measurements. The $\mathrm{pH}$ value was recorded after the reading was stable. The measured $\mathrm{pH}$ results are shown in Figure 11. It can be seen the $\mathrm{pH}$ of the OPC paste increased with the increase of $\mathrm{Na}_{2} \mathrm{CO}_{3}$ but it decreased with the increase of $\mathrm{NaHCO}_{3}$. This was caused by the different $\mathrm{pH}$ of the solutions with the same amount of $\mathrm{Na}_{2} \mathrm{CO}_{3}$ and $\mathrm{NaHCO}_{3}$. There could be a risk of alkali silica reaction in the concrete with a high amount of $\mathrm{Na}_{2} \mathrm{CO}_{3}$ because of the increased $\mathrm{pH}$. There could be a decay of the $\mathrm{C}-\mathrm{S}-\mathrm{H}$ gel in the concrete with a high amount of $\mathrm{NaHCO}_{3}$ because of the decreased $\mathrm{pH}$.

$$
\begin{gathered}
\mathrm{Na}_{2} \mathrm{CO}_{3} \rightarrow 2 \mathrm{Na}^{+}+\mathrm{CO}_{3}{ }^{2-} \\
\mathrm{NaHCO}_{3} \rightarrow \mathrm{Na}^{+}+\mathrm{HCO}_{3}{ }^{-} \\
\mathrm{Na}_{2} \mathrm{CO}_{3}+\mathrm{Ca}(\mathrm{OH})_{2}=\mathrm{CaCO}_{3} \downarrow+2 \mathrm{NaOH} \\
\mathrm{NaHCO}_{3}+\mathrm{Ca}(\mathrm{OH})_{2}=\mathrm{NaOH}+\mathrm{CaCO}_{3} \downarrow+\mathrm{H}_{2} \mathrm{O}
\end{gathered}
$$




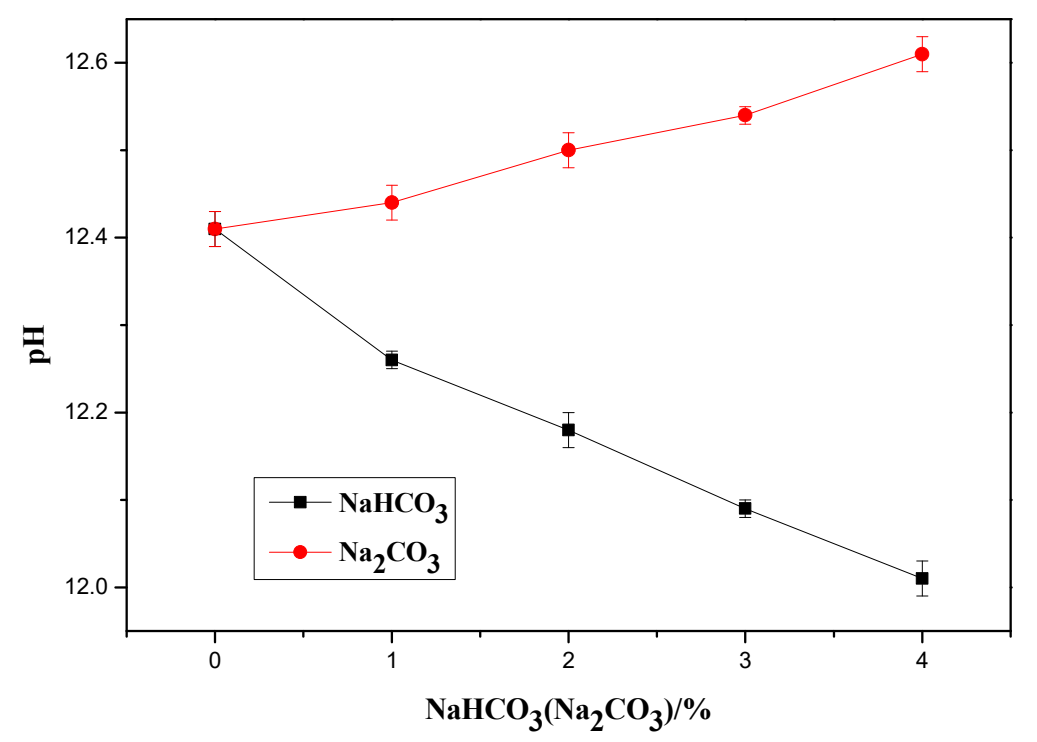

Figure 11. $\mathrm{pH}$ of fresh cement paste with $\mathrm{Na}_{2} \mathrm{CO}_{3}$ or $\mathrm{NaHCO}_{3}$.

\subsection{Influence of $\mathrm{Na}_{2} \mathrm{CO}_{3} / \mathrm{NaHCO}_{3}$ on the Introduced $\mathrm{CO}_{2}$}

In $\mathrm{Na}_{2} \mathrm{CO}_{3}$ the weight of $\mathrm{Na}^{+}$is $43.4 \%$ and the weight of $\mathrm{CO}_{2}$ is $41.5 \%$. In $\mathrm{NaHCO}_{3}$ the weight of $\mathrm{Na}^{+}$is $27.4 \%$ and the weight of $\mathrm{CO}_{2}$ is $52.4 \%$. It can be seen that, when the same weight of the two are used, $\mathrm{NaHCO}_{3}$ brings $16 \%$ less $\mathrm{Na}^{+}$and $10.9 \%$ more $\mathrm{CO}_{2}$ into the cement paste. Although the $\mathrm{Na}^{+}$is believed to accelerate the initial hydration and early age strength [37], it is thought that $\mathrm{Na}^{+}$is responsible for the adverse effect on the later age strength development of the cement paste with salts containing $\mathrm{Na}^{+}$[20]. The adverse effect of $\mathrm{Na}^{+}$on the strength development can be explained that the $\mathrm{Na}^{+}$could affect the adhesion between C-S-H gel structure (Figure 12a) by reaction with the silica phase in the cement paste and form sodium orthosilicate (Figure 12b) $[38,39]$. The difference of $\mathrm{Na}^{+}$ introduced by the two was thought to be the main reason that the paste with $\mathrm{NaHCO}_{3}$ had a better later stage strength development than that with $\mathrm{Na}_{2} \mathrm{CO}_{3}$.

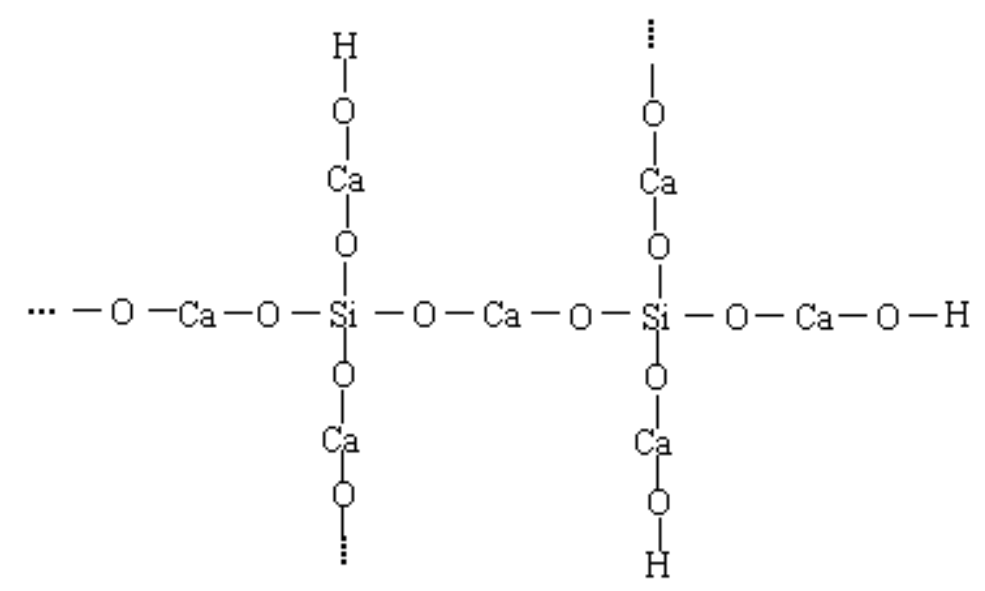

a<smiles>[M]O[Si](O[Na])(O[AlH2])O[AlH2]</smiles>

b

Figure 12. Sketch of the structure of C-S-H gel (a) and sodium orthosilicate (b).

\subsection{Influence of $\mathrm{Na}_{2} \mathrm{CO}_{3} / \mathrm{NaHCO}_{3}$ on the Formation of Ettringite and $\mathrm{CaCO}_{3}$}

The initial difference between the effects of the $\mathrm{Na}_{2} \mathrm{CO}_{3}$ and $\mathrm{NaHCO}_{3}$ on the setting time and early age strength can be explained by the following reasons. In the paste with $\mathrm{Na}_{2} \mathrm{CO}_{3}$ the initial reactions were as Equations (3) and (5)-(7), and there was formation of both $\mathrm{CaCO}_{3}$ and ettringite. While in the paste with $\mathrm{NaHCO}_{3}$ the initial reactions were as Equations (4), (5), and (7), and there was 
no initial formation of $\mathrm{CaCO}_{3}$ and there was only formation of ettringite. There could be less ettringite formed in the paste with $\mathrm{Na}_{2} \mathrm{CO}_{3}$ compared to that with $\mathrm{NaHCO}_{3}$ because of the initial consumption of $\mathrm{Ca}^{2+}$ with $\mathrm{CO}_{3}{ }^{2-}$. This could contribute to the better initial performance and shorter setting time of the paste with $\mathrm{NaHCO}_{3}$. In the paste with $\mathrm{NaHCO}_{3}$ the formation of $\mathrm{CaCO}_{3}$ happened at a later stage as Equations (8) and (9), and the later stage formed $\mathrm{CaCO}_{3}$ particles could contribute to fill the microand nano-pores of the C-S-H gel.

$$
\begin{gathered}
\mathrm{CaSO}_{4} \bullet 2 \mathrm{H}_{2} \mathrm{O} \rightarrow \mathrm{Ca}^{2+}+\mathrm{SO}_{4}{ }^{2-}+2 \mathrm{H}_{2} \mathrm{O} \\
\mathrm{CO}_{3}{ }^{2-}+\mathrm{Ca}^{2+} \rightarrow \mathrm{CaCO}_{3} \downarrow \\
3 \mathrm{CaO} \bullet \mathrm{Al}_{2} \mathrm{O}_{3}+3\left(\mathrm{CaSO}_{4} \bullet 2 \mathrm{H}_{2} \mathrm{O}\right)+26 \mathrm{H}_{2} \mathrm{O} \rightarrow 3 \mathrm{CaO}_{2} \mathrm{Al}_{2} \mathrm{O}_{3} \bullet 3 \mathrm{CaSO}_{4} \bullet 32 \mathrm{H}_{2} \mathrm{O} \\
\mathrm{C}_{3} \mathrm{~S}+\mathrm{H}_{2} \mathrm{O} \rightarrow \mathrm{C}-\mathrm{S}-\mathrm{H}+\mathrm{Ca}^{2+}+\mathrm{OH}^{-} \\
\mathrm{HCO}_{3}{ }^{-}+\mathrm{Ca}^{2+}+\mathrm{OH}^{-} \rightarrow \mathrm{CaCO}_{3} \downarrow+\mathrm{H}_{2} \mathrm{O}
\end{gathered}
$$

\subsection{Influence of $\mathrm{Na}_{2} \mathrm{CO}_{3} / \mathrm{NaHCO}_{3}$ on the Enthalpies of the Reactions with $\mathrm{C}_{3} \mathrm{~S}$}

In order to further investigate the effect of $\mathrm{Na}_{2} \mathrm{CO}_{3}$ and $\mathrm{NaHCO}_{3}$ on the hydration of $\mathrm{C}_{3} \mathrm{~S}$, the enthalpies of the reactions are calculated. The enthalpies of all the reactants and products were calculated by the first-principles and the module of total energy pseudopotential calculations in the Vienna Ab initio Simulation Package (VASP) [40] was used for the calculations.

$$
\begin{gathered}
2\left(3 \mathrm{CaO} \cdot \mathrm{SiO}_{2}\right)+6 \mathrm{H}_{2} \mathrm{O}=3 \mathrm{CaO} \cdot 2 \mathrm{SiO}_{2} \cdot 3 \mathrm{H}_{2} \mathrm{O}+3 \mathrm{Ca}(\mathrm{OH})_{2} \\
\mathrm{Ca}(\mathrm{OH})_{2}+\mathrm{Na}_{2} \mathrm{CO}_{3}=\mathrm{CaCO}_{3}+2 \mathrm{NaOH} \\
\mathrm{Ca}(\mathrm{OH})_{2}+\mathrm{NaHCO}_{3}=\mathrm{CaCO}_{3}+\mathrm{NaOH}+\mathrm{H}_{2} \mathrm{O} \\
3 \mathrm{CaO} \cdot 2 \mathrm{SiO}_{2} \cdot 3 \mathrm{H}_{2} \mathrm{O}+2 \mathrm{NaOH}=\mathrm{Na}_{2} \mathrm{O} \cdot 2 \mathrm{CaO} \cdot 2 \mathrm{SiO}_{2} \cdot \mathrm{H}_{2} \mathrm{O}+\mathrm{Ca}(\mathrm{OH})_{2}+\mathrm{H}_{2} \mathrm{O}
\end{gathered}
$$

By combing Equations (10), (11) and (13), resulting Equation (14)

$$
2\left(3 \mathrm{CaO} \cdot \mathrm{SiO}_{2}\right)+\mathrm{Na}_{2} \mathrm{CO}_{3}+4 \mathrm{H}_{2} \mathrm{O}=\mathrm{Na}_{2} \mathrm{O} \cdot 2 \mathrm{CaO} \cdot 2 \mathrm{SiO}_{2} \cdot \mathrm{H}_{2} \mathrm{O}+\mathrm{CaCO}_{3}+3 \mathrm{Ca}(\mathrm{OH})_{2}
$$

By combing Equations (10), (12) and (13), resulting Equation (15)

$$
2\left(3 \mathrm{CaO} \cdot \mathrm{SiO}_{2}\right)+2 \mathrm{NaHCO}_{3}+2 \mathrm{H}_{2} \mathrm{O}=\mathrm{Na}_{2} \mathrm{O} \cdot 2 \mathrm{CaO} \cdot 2 \mathrm{SiO}_{2} \cdot \mathrm{H}_{2} \mathrm{O}+2 \mathrm{CaCO}_{3}+2 \mathrm{Ca}(\mathrm{OH})_{2}
$$

The enthalpy of the reactions in Equation (14) $\left(E_{\text {reaction14 }}\right)$ can be calculated by Equation (16) and the value was $-0.02903 \mathrm{eV} /$ atom. The enthalpy of the reactions in Equation (15) ( $\mathrm{E}_{\text {reaction15 }}$ ) can be calculated by Equation (17) and the value was $-0.04306 \mathrm{eV} /$ atom. These negative values suggest that the reactions in Equations (14) and (15) are both exothermic and can proceed spontaneously in thermodynamics. The reaction in Equation (15) had a more negative value than that in Equation (14) and it means that the reaction in Equation (15) is much easier to happen than that in Equation (14), which suggests that the reaction between $\mathrm{C}_{3} \mathrm{~S}$ and $\mathrm{NaHCO}_{3}$ is much easier that the reaction between $\mathrm{C}_{3} \mathrm{~S}$ and $\mathrm{Na}_{2} \mathrm{CO}_{3}$.

$$
\begin{gathered}
\mathrm{E}_{\text {reaction14 }}=\left(\mathrm{E}_{\mathrm{Na} 2 \mathrm{O} \cdot 2 \mathrm{CaO} \cdot 2 \mathrm{SiO} 2 \cdot \mathrm{H} 2 \mathrm{O}} \times 16+\mathrm{E}_{\mathrm{CaCO} 3} \times 5+\mathrm{E}_{\mathrm{Ca}(\mathrm{OH}) 2} \times 15-\mathrm{E}_{3 \mathrm{CaO} \cdot \mathrm{SiO} 2} \times\right. \\
\left.18-\mathrm{E}_{\mathrm{Na} 2 \mathrm{CO} 3} \times 6-\mathrm{E}_{\mathrm{H} 2 \mathrm{O}} \times 12\right) / 36 \\
\mathrm{E}_{\text {reaction15 }}=\left(\mathrm{E}_{\mathrm{Na} 2 \mathrm{O} \cdot 2 \mathrm{CaO} \cdot 2 \mathrm{SiO} 2 \cdot \mathrm{H} 2 \mathrm{O}} \times 16+\mathrm{E}_{\mathrm{CaCO} 3} \times 10+\mathrm{E}_{\mathrm{Ca}(\mathrm{OH}) 2} \times 10-\mathrm{E}_{3 \mathrm{CaO} \cdot \mathrm{SiO} 2} \times\right. \\
\left.18-\mathrm{E}_{\mathrm{NaHCO} 3} \times 18-\mathrm{E}_{\mathrm{H} 2 \mathrm{O}} \times 6\right) / 36
\end{gathered}
$$




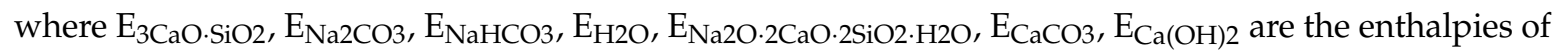
$3 \mathrm{CaO} \cdot \mathrm{SiO}_{2}, \mathrm{Na}_{2} \mathrm{CO}_{3}, \mathrm{NaHCO}_{3}, \mathrm{H}_{2} \mathrm{O}, \mathrm{Na}_{2} \mathrm{O} \cdot 2 \mathrm{CaO} \cdot 2 \mathrm{SiO}_{2} \cdot \mathrm{H}_{2} \mathrm{O}, \mathrm{CaCO}_{3}$, and $\mathrm{Ca}(\mathrm{OH})_{2}$ molecules in unit of $\mathrm{eV} /$ atom, respectively.

\section{Conclusions}

The influence of $\mathrm{NaHCO}_{3}$ and $\mathrm{Na}_{2} \mathrm{CO}_{3}$ as additional additives on the setting time and compressive strength of OPC paste was investigated and the related effect on the hydration mechanism was studied through TG-DTA, XRD, and SEM tests. The following conclusions can be drawn.

(1) The initial and final setting time of OPC paste decreased with the increase of either $\mathrm{NaHCO}_{3}$ or $\mathrm{Na}_{2} \mathrm{CO}_{3}$.

(2) The addition of either $\mathrm{NaHCO}_{3}$ or $\mathrm{Na}_{2} \mathrm{CO}_{3}$ could increase the early age compressive strength ( 1 and 7 days) depending on the content added but they could decrease the compressive strength at later ages, such as 28 days, with the increase of content added.

(3) As an accelerator, the optimum content of $\mathrm{NaHCO}_{3}$ and $\mathrm{Na}_{2} \mathrm{CO}_{3}$ were found to be in the same level as $1 \%$ of the weight of OPC. The addition $1 \%$ of either of the two accelerators could significantly shorten the setting time, increase the early age strength and did not have an obvious detrimental effect on the later age strength.

(4) Further increase of $\mathrm{NaHCO}_{3}$ and $\mathrm{Na}_{2} \mathrm{CO}_{3}$ above $1 \%$ could decrease the compressive strength of OPC paste although the ettringite formation was accelerated and increased. This decay was mainly caused by the $\mathrm{Na}^{+}$ions introduced and the $\mathrm{Na}^{+}$could partly replace the $\mathrm{Ca}^{2+}$ in the C-S-H gel and cause the discontinuity of the C-S-H gel.

(5) $\mathrm{NaHCO}_{3}$ was seen to be a better option as an accelerator compared to $\mathrm{Na}_{2} \mathrm{CO}_{3}$. The reaction between $\mathrm{NaHCO}_{3}$ and $\mathrm{C}_{3} \mathrm{~S}$ was found to be much easier than the reaction between $\mathrm{Na}_{2} \mathrm{CO}_{3}$ and $\mathrm{C}_{3} \mathrm{~S}$. The same amount addition of $\mathrm{NaHCO}_{3}$ resulted a higher compressive strength at all ages compared to $\mathrm{NaHCO}_{3}$. Besides, $\mathrm{NaHCO}_{3}$ the introduced less $\mathrm{Na}^{+}$and more $\mathrm{CO}_{2}$ in the cementitious system than the $\mathrm{Na}_{2} \mathrm{CO}_{3}$ when the same amount of the two were used.

Author Contributions: Conceptualization and Supervision: J.W., Q.H.; Methodology: J.W., Y.W., F.H.; Analysis: J.W., F.H., and Y.W., Writing and Editing: Y.W., F.H., and J.W.

Funding: The supports from the National Key Research and Development Plan of China (2017YFC0603004), the National Natural Science Foundation of China (51678220), the Program for Innovation Scientists and Technicians Troop Construction Projects of Henan Province in China (CXTD2017088) and the Program for Innovative Research Team (in Science and Technology) (19IRTSTHN027) in Henan Polytechnic University are appreciated. The authors appreciate the support from the Engineering division in New York University Abu Dhabi, UAE.

Conflicts of Interest: The authors declare no conflict of interest.

\section{References}

1. Ma, B.; Ma, M.; Shen, X.; Li, X.; Wu, X. Compatibility between a polycarboxylate superplasticizer and the belite-rich sulfoaluminate cement: Setting time and the hydration properties. Constr. Build. Mater. 2014, 51, 47-54. [CrossRef]

2. Bamonte, P.; Gambarova, P.G.; Nafarieh, A. High-temperature behavior of structural and non-structural shotcretes. Cem. Concr. Compos. 2016, 73, 42-53. [CrossRef]

3. De Belie, N.; Grosse, C.U.; Kurz, J.; Reinhardt, H. Ultrasound monitoring of the influence of different accelerating admixtures and cement types for shotcrete on setting and hardening behaviour. Cem. Concr. Res. 2005, 35, 2087-2094. [CrossRef]

4. Won, J.; Choi, B.; Lee, J. Experimental and statistical analysis of the alkali-silica reaction of accelerating admixtures in shotcrete. Constr. Build. Mater. 2012, 30, 330-339. [CrossRef]

5. Xie, J.; Wang, J.; Rao, R.; Wang, C.; Fang, C. Effects of combined usage of GGBS and fly ash on workability and mechanical properties of alkali activated geopolymer concrete with recycled aggregate. Compos. B Eng. 2019, 164, 179-190. [CrossRef] 
6. Hou, P.; Kawashima, S.; Kong, D.; Corr, D.J.; Qian, J.; Shah, S.P. Modification effects of colloidal nano $\mathrm{SiO}_{2}$ on cement hydration and its gel property. Compos. B Eng. 2013, 45, 440-448. [CrossRef]

7. Meng, T.; Yu, Y.; Wang, Z. Effect of nano-CaCO3 slurry on the mechanical properties and micro-structure of concrete with and without fly ash. Compos. B Eng. 2017, 117, 124-129. [CrossRef]

8. Nazari, A.; Riahi, S. The effects of zinc dioxide nanoparticles on flexural strength of self-compacting concrete. Compos. B Eng. 2011, 42, 167-175. [CrossRef]

9. Jalal, M.; Ramezanianpour, A.A.; Pool, M.K. Split tensile strength of binary blended self compacting concrete containing low volume fly ash and $\mathrm{TiO}_{2}$ nanoparticles. Compos B Eng. 2013, 55, 324-337. [CrossRef]

10. Brough, A.R.; Atkinson, A. Sodium silicate-based. alkali-activated slag mortars: Part I. Strength, hydration and microstructure. Cem. Concr. Res. 2002, 32, 865-879. [CrossRef]

11. Li, G.; Li, C.; Zhou, W.; Wu, Y. Factors affecting the liquid sodium aluminate accelerated agent. Concrete 2005, 7, 54-58.

12. Han, J.; Wang, K.; Shi, J.; Wang, Y. Influence of sodium aluminate on cement hydration and concrete properties. Constr. Build. Mater. 2014, 64, 342-349. [CrossRef]

13. Tu, Z.; Shi, C.; Farzadnia, N. Effect of Limestone Powder Content on the Early-Age Properties of $\mathrm{CO}_{2}-\mathrm{Cured}$ Concrete. J. Mater. Civ. Eng. 2018, 30, 04018164. [CrossRef]

14. Chong, L.; Shi, C.; Yang, J.; Jia, H. Effect of limestone powder on the water stability of magnesium phosphate cement-based materials. Constr. Build. Mater. 2017, 148, 590-598. [CrossRef]

15. Wu, Z.; Shi, C.; Khayat, K.H. Multi-scale investigation of microstructure, fiber pullout behavior, and mechanical properties of ultra-high performance concrete with nano- $\mathrm{CaCO}_{3}$ particles. Cem. Concr. Compos. 2018, 86, 255-265. [CrossRef]

16. Li, W.; Huang, Z.; Zu, T.; Shi, C.; Duan, W.H.; Shah, S.P. Influence of Nanolimestone on the Hydration, Mechanical Strength, and Autogenous Shrinkage of Ultrahigh-Performance Concrete. J. Mater. Civ. Eng. 2016, 28, 04015068. [CrossRef]

17. Tu, Z.; Guo, M.; Poon, C.S.; Shi, C. Effects of limestone powder on $\mathrm{CaCO}_{3}$ precipitation in $\mathrm{CO}_{2}$ cured cement pastes. Cem. Concr. Compos. 2016, 72, 9-16. [CrossRef]

18. Monosi, S.; Moriconi, G.; Collepardi, M. Combined effect of lignosulfonate and carbonate on pure portland clinker compounds hydration. III. Hydration of tricalcium silicate alone and in the presence of tricalcium aluminate. Cem. Concr. Res. 1982, 12, 425-435. [CrossRef]

19. Krismahariyanto, M.; Saing, B.; Widodo, H. The Effects of Sodium Carbonate on the Properties and the Hydration of the Cement Mixed with the Hardening Accelerator Based on Calcium-Aluminate. AIP Conf. Proc. 2017, 1877, 090002.

20. Jang, J.G.; Kim, H.J.; Park, S.M.; Lee, H.K. The influence of sodium hydrogen carbonate on the hydration of cement. Constr. Build. Mater. 2015, 94, 746-749. [CrossRef]

21. Yang, H.; Che, Y. Effects of Nano-CaCO 3 /Limestone Composite Particles on the Hydration Products and Pore Structure of Cementitious Materials. Adv. Mater. Sci. Eng. 2018, 2018, 8. [CrossRef]

22. Bernardi, A.; Bortoluzzi, E.A.; Felippe, W.T.; Felippe, M.C.S.; Wan, W.S.; Teixeira, C.S. Effects of the addition of nanoparticulate calcium carbonate on setting time, dimensional change, compressive strength, solubility and pH of MTA. Int. Endod. J. 2017, 50, 97-105. [CrossRef] [PubMed]

23. Mathur, R.; Sharma, S.K. Magnesium oxysulphate cement: Change in properties on admixing sodium bicarbonate as an additive. Rasayan J.Chem. 2008, 1, 620-630.

24. Chandrawat, M.P.S.; Yadav, R.N. Effect of sodium carbonate on some properties of magnesia cement. J. Indian Chem. Soc. 2001, 78, 389-391.

25. Kunther, W.; Lothenbach, B.; Scrivener, K. Influence of bicarbonate ions on the deterioration of mortar bars in sulfate solutions. Cem. Concr. Res. 2013, 44, 77-86. [CrossRef]

26. Kerui, Y.; Caiwen, Z.; Zhigang, L. The influence of calcium lignosulphonate-sodium bicarbonate on the status of ettringite crystallization in fly ash cement paste. Cem. Concr. Res. 2002, 32, 51-56. [CrossRef]

27. Reddy, V.V.; Rao, H.S.; Jayaveera, K.N. Influence of strong alkaline substances (sodium carbonate and sodium bicarbonate) in mixing water on strength and setting properties of concrete. Indian J. Eng. Mater. Soc. 2006, 13, 123-128.

28. Reddy, L.V.G.; Krishna, B. Influence of $\mathrm{Na}_{2} \mathrm{CO}_{3}, \mathrm{NaHCO}_{3}$ and Organic Substances (Algae) in Water on Physical Properties of Blended Pozzolonic Portland Cement. Int. J. Eng. Res. Technol. (IJERT). 2014, 3, 35-41. 
29. Golewski, G.L. Evaluation of morphology and size of cracks of the Interfacial Transition Zone (ITZ) in concrete containing fly ash (FA). J. Hazard. Mater. 2018, 357, 298-304. [CrossRef]

30. Golewski, G.L. An assessment of microcracks in the Interfacial Transition Zone of durable concrete composites with fly ash additives. Compos. Struct. 2018, 200, 515-520. [CrossRef]

31. Standardization Administration of the People's Republic of China. GB175-2007: Common Portland Cement; China Architecture and Building Press: Beijing, China, 2007.

32. Ministry of Housing and Urban-Rural Development. JC 477-2005 Flash Setting Admixtures for Shotcrete; Ministry of Housing and Urban-Rural Development: Beijing, China, 2005.

33. Zhang, Y.; Wang, Y.; Li, T.; Xiong, Z.; Sun, Y. Effects of lithium carbonate on performances of sulphoaluminate cement-based dual liquid high water material and its mechanisms. Constr. Build. Mater. 2018, 161, 374-380. [CrossRef]

34. Xiong, Z.; Wang, P.; Wang, Y. Hydration Behaviors of Portland Cement with Different Lithologic Stone Powders. Int. J. Concr. Struct. Mater. 2015, 9, 55-60. [CrossRef]

35. Bensted, J.; Barnes, P. Structure \& Performance of Cements; Taylor \& Francis e-Library: London, UK; New York, NY, USA, 2008; pp. 90-91.

36. Bullard, J.W.; Jennings, H.M.; Livingston, R.A.; Nonat, A.; Scherer, G.W.; Schweitzer, J.S.; Scrivener, K.L.; Thomas, J.J. Mechanisms of cement hydration. Cem. Concr. Res. 2011, 41, 1208-1223. [CrossRef]

37. Edwards, G.C.; Angstadt, R.L. The effect of some soluble inorganic admixtures on the early hydration of portland cement. J. Appl. Chem. 2007, 16, 166-168. [CrossRef]

38. Abdalqader, A.F.; Jin, F.; Al-Tabbaa, A. Development of greener alkali-activated cement: Utilisation of sodium carbonate for activating slag and fly ash mixtures. J. Clean. Prod. 2016, 113, 66-75. [CrossRef]

39. Yuan, B.; Straub, C.; Segers, S.; Yu, Q.L.; Brouwers, H.J.H. Sodium carbonate activated slag as cement replacement in autoclaved aerated concrete. Ceram. Int. 2017, 43, 6039-6047. [CrossRef]

40. Kresse, G.; Furthmuller, J. Efficient iterative schemes for ab initio total-energy calculations using a plane-wave basis set. Phys. Rev. B 1996, 54, 11169-11186. [CrossRef]

(C) 2019 by the authors. Licensee MDPI, Basel, Switzerland. This article is an open access article distributed under the terms and conditions of the Creative Commons Attribution (CC BY) license (http:/ / creativecommons.org/licenses/by/4.0/). 